\title{
Descubrir verdades desvelando apariencias: la apertura de la cortina como puesta en escena del saber en el Siglo de Oro ${ }^{1}$
}

\author{
Héctor Ruiz Soto ${ }^{2}$
}

Recibido: 1 de julio de 2020 / Aceptado: 27 de abril de 2021 .

Resumen. El presente artículo analiza dos dispositivos editoriales originales, que recurren al desvelamiento como puesta en escena de la lectura y de la adquisición de conocimientos: los frontispicios ilustrados con cortinas y la Navegación para el cielo, un poema con estampas desplegable en el que la lectura es una sucesión de descubrimientos. La primera parte del artículo pone estos objetos en relación con el patrón espectacular de la "apariencia" y con los usos teatrales y rituales de la cortina en los mundos de la comedia, de la liturgia, del ceremonial real y del coleccionismo artístico. A la dignidad y la maravilla propias de este espectáculo del descubrimiento, se asocia la sorpresa de una revelación. La segunda parte estudia los frontispicios y la Navegación para el cielo explorando las implicaciones epistemológicas asociadas al instante del desvelamiento propio de la apariencia.

Palabras clave. Apariencia; cortina; frontispicios; Navegación para el cielo; epistemología

\section{[en] Discovering truths by revealing "apariencias": unveiling as a staging of knowledge in Spanish Golden Age}

\begin{abstract}
This article analyses two original editorial devices, which use unveiling as a staging of reading and knowledge acquisition: the frontispieces illustrated with curtains and the Navegación para el cielo, a fold-out illustrated poem, in which reading is a succession of discoveries. The first part of the article relates these objects to the spectacular pattern known as "apariencia", and to the theatrical and ritual uses of the curtain in the worlds of drama, liturgy, royal ceremony and art collecting. The dignity and wonder of this spectacle of discovery are linked to the surprise of a revelation. The second part studies the frontispieces and the Navegación, exploring the epistemological implications associated to the instant of the unveiling, characteristic of the "apariencia".
\end{abstract}

Keywords. Unveiling; curtain; frontispieces; Navegación para el cielo; epistemology

Sumario: Espectáculos del conocimiento: cortinas de papel y apariencias editoriales. El frontispicio con cortina: el mercado editorial de los descubrimientos. Leer y revelar imágenes: el descubrimiento como activación del saber y la temporalidad de la apariencia. Conclusión: el conocimiento de la "apariencia" y las transformaciones de la imagen. Bibliografía.

\footnotetext{
Agradezco a Fernando Bouza que el 23 de noviembre de 2019 me diera a conocer la Carta del cartujo. Este artículo le debe mucho a sus sugerencias de ese día, así como a las de Ralph Dekoninck y Cécile Vincent-Cassy, y a la lectura de Mercedes Blanco, Fernando Bouza, David Ruiz y los revisores de este trabajo.

2 École Normale Supérieure - Paris Sciences et Lettres

Email: hector.ruiz.soto@ens.psl.eu; hector.ruiz@casadevelazquez.org

ORCID: https://orcid.org/0000-0003-3315-5714
} 
Cómo citar: Ruiz Soto, H. (2021). Descubrir verdades desvelando apariencias: la apertura de la cortina como puesta en escena del saber en el Siglo de Oro, en Cuadernos de Historia Moderna 46.1, 115-145.

\author{
Platón, \\ a lo que en cosas divinas \\ escribió, puso cortinas \\ que, tales como estas, son \\ matemáticas figuras \\ y enigmas ${ }^{3}$.
}

El tema de este artículo es una metáfora, su extensión y sus implicaciones en la historia cultural del Siglo de Oro: "correr la cortina significa algunas veces hacer demostración de algún caso maravilloso" ". La cortina, en la "cosmovisión" barroca, podría ser un emblema del "carácter fenoménico, aparencial" 5 de la realidad que Maravall estudió en La cultura del Barroco. Como velo que encubre o que desvela, responde a la doble faceta de las apariencias, como engaño que se somete a la crítica y como aspecto veraz que alimenta la experiencia del mundo. Según escribía Maravall, "conocer es descifrar el juego de las apariencias"6, y en este caso levantar la cortina del engaño para acceder a la visión de la realidad. Y es que la cortina y el velo tienen un carácter ambivalente, para encubrir tanto como para revelar. Dejando de lado el tema del velo del engaño ${ }^{7}$, atendemos a la cortina que protege un saber oculto, como en los versos de La dama boba de Lope de Vega que traemos como epígrafe. Y es que en el teatro, tanto como en la iconografía y en el ritual, el desvelamiento permite acceder a la visión de un conocimiento superior de la realidad y transmitir un aprendizaje visual al espectador, de forma alegórica pero también de forma efectiva y espectacular ${ }^{8}$.

A medio camino entre las revelaciones exegéticas y la divulgación de saberes considerados como prohibidos, la extensión del desvelamiento como figura del aprendizaje muestra un mundo en el que la ciencia, la religión y la maravilla están intrínsecamente ligadas por una misma puesta en escena espectacular del saber y el conocimiento. El desengaño sería una de las formas más conocidas de estas demostraciones espectaculares, en las que la cortina no encubre sino que revela: un ejemplo destacado se encuentra en el romance "No piensen, aunque soy niño...", atribuido apócrifamente a Luis de Góngora. Se trata de una de esas letrillas satíricas basadas en el modelo de los avisos para manejarse en la corte, como la célebre carta de Juan

\footnotetext{
Vega Carpio, L.: La dama boba, v. 579-584.

4 Covarrubias, S.: Tesoro de la lengua castellana o española, ed. I. Arellano y R. Zafra, Pamplona, Madrid y Fráncfort, Universidad de Navarra, Iberoamericana-Vervuert, 2006, pp. 619-620.

5 Maravall, J.A.: La cultura del Barroco. Análisis de una estructura histórica, Barcelona, Ariel, 1975, pp. 391392.

Ibidem, p. 393.

Sobre el engaño, Rodríguez de la Flor, F.: Pasiones frías. Secreto y disimulación en el Barroco hispano, Madrid, Madrial Pons, 2005.

8 Sobre el telón como jeroglífico Egido, A.: "Telones parlantes del Siglo de Oro", en Blecua, L. A., Arellano, I., y Serés, G. (eds.): El teatro del Siglo de Oro: edición e interpretación, Pamplona/Madrid, Universidad de Navarra/Iberoamericana, pp. 113-173; y sobre la apariencia como forma escénica de la verdad Ruiz Soto, H.: “Monstruos de apariencias llenos? Las escenas de descubrimiento y la cortina de apariencias en los manuscritos teatrales de Gondomar y de Palacio”, Criticón, 140 (2020), pp. 27-51.
} 
de Vega a su hijo ${ }^{9}$. En este poema, el padre del niño en cuestión le avisa del engaño de las falsas apariencias cortesanas:

\author{
Mira que vas a una tierra \\ que es Egipto en sabandijas, \\ y que si eres pecador \\ te han de dar amarga vida; \\ mira que allí las mujeres \\ altas, pobres, bajas, ricas, \\ como sanguijuelas dan, \\ sin sentirse, las sangrías; \\ $[\ldots .$. \\ y si vieres faldellines \\ y recamadas basquiñas, \\ mira cuál queda la imagen \\ en corriendo la cortina ${ }^{10}$.
}

El joven ha de abrir la cortina de los engaños para descubrir la verdadera imagen: "mira cuál queda la imagen / en corriendo la cortina". Los versos siguientes desvelan al lector esa verdad oculta, que se manifiesta como un espectáculo revelado: "Hay damas que, en hinchazón, / a los pavones imitan / mas mirándose a los pies / se entristecen y se humillan". La sátira misógina contra doncellas, casadas y viudas remite a una escenografía de desvelamiento que figura el desengaño, y cuya dignidad contrasta con los mentirosos vestidos de las seductoras. Este contraste entre la verdad del desvelamiento y el engaño de los afeites es recurrente. León Pinelo, en sus Velos antiguos y modernos en los rostros de las mujeres, también opone los velos de las cortesanas, tapadas de medio ojo ${ }^{11}$, con los velos decentes de las mujeres dignas, a su vez comparables con los de los retablos. El interés de la metáfora del desvelamiento como figura de la verdad, radica precisamente en su correspondencia con los retablos cortinados, y en general con una serie de representaciones y rituales que sitúan la apertura de la cortina del lado de la majestad, la dignidad, lo sagrado y lo admirable.

Un primer ámbito donde el desvelamiento juega un papel relevante es el de los rituales litúrgicos. El más conocido, todavía en vigor en multitud de iglesias, es el

Bouza, F.: Imagen y propaganda. Capitulos de historia cultural del reinado de Felipe II, Madrid, Akal, 1998, pp. 219-228. Sobre la fortuna de este modelo, véase Baranda, N.: "Los nobles toman cartas en la educación de sus vástagos", en García de Enterría, M. C. y Cordón Mesa, A. (eds.): Actas del IV Congreso Internacional de la Asociación Internacional Siglo de Oro, Alcalá, Universidad de Alcalá de Henares, 1998, vol. 1, pp. 215-224, y Carvalho, J. A. F.: Pais e nobres. I. Cartas de instrução de jovens nobres (séculos XVI-XVII), II. A descendência portuguesa de um texto célebre: A Instrucción de Juan de Vega a seu filho Hernando de Vega (1548), Porto, Centro Inter-Universitário de História da Espiritualidade, 2009.

10 "No piensen, aunque soy niño...", v. 13-20 y 49-52, en Góngora, L.: Romances, ed. A. Carreira, Barcelona, Quaderns Crema, 1998, vol. IV, pp. 364-366. A continuación cito los vv. 53-56.

11 León Pinelo, A., Velos antiguos y modernos en los rostros de las mujeres: sus convenencias y daños: ilustración de la Real Premática de las tapadas..., En Madrid, por Iuan Sanchez, 1641, fols. 10v-11r y 122v-123r. Véase también Bass, L. y Peraita, C., “'Cubriendo y velando en la primera hoja': Antonio León Pinelo y los contextos culturales de Velos antiguos i modernos (1641)", en Martín, A.L. y Quintero, M.C. (eds.), Perspectives on Early Modern Women in Iberia and the Americas: Studies in Law, Society, Art and Literature in Honor of Anne J. Cruz, Nueva York, Escribana Books, 2015, pp. 615-631. 
descubrimiento de las imágenes eclesiásticas el domingo de Resurrección, tras su ocultamiento durante la cuaresma. En la Europa católica, famosas reliquias como las cabezas de los apóstoles Pedro y Pablo en la iglesia romana de San Juan de Letrán se mostraban abriendo una cortina ${ }^{12}$. El Santo Sudario de Oviedo, según Ambrosio de Morales, se mostraba de la misma manera ${ }^{13}$. Tanto en ritos anuales como en fiestas ocasionales, tanto en escenografías con verdaderas cortinas como en representaciones con velos fingidos, el desvelamiento pertenece al acervo espectacular de la Iglesia católica.

El desvelamiento aparece también en un segundo ámbito: el ceremonial real propio de los Habsburgo españoles. Según el rito borgoñón impuesto por Carlos $\mathrm{V}$ en 1548 y preservado hasta el final de la dinastía, el rey asistía a los oficios desde un oratorio cortinado, la "cortina real" 14 . Ante los grandes del reino y los embajadores católicos en la corte, la mano del sumiller de cortina descubría u ocultaba el espectáculo del rey católico. Lejos de ser el tópico rey escondido, el monarca se mostraba así de manera excepcional, ofreciendo una imagen de hieratismo y majestad capaces de maravillar a quien tuviera el privilegio de contemplarlo, empezando por el envidiado sumiller.

Más allá del ámbito ceremonial, el desvelamiento corresponde también a una práctica expositiva en la esfera de las colecciones privadas de pintura españolas y europeas. Según el inventario testamentario de Pompeo Leoni, al menos seis imágenes tenían una cortina añadida al marco, y entre ellas obras de Rafael, de Luini o del Parmigianino, como la Sagrada Familia del Prado, la obra más preciada de su colección ${ }^{15}$. Esta práctica expositiva se desarrolla en paralelo a sus referentes rituales, adaptando el prestigio ceremonial o la simbología litúrgica al ámbito privado, y añadiendo a esta puesta en escena otros valores, como el deseo propio del desnudo en las poesías mitológicas o el terror ante los casos sangrientos, temas habitualmente velados en varias colecciones de pintura ${ }^{16}$.

Por último, el mundo del teatro ofrece un último campo de estudio del desvelamiento espectacular en la temprana edad moderna española. En el teatro de corral, la tramoya conocida como "apariencia" consistía precisamente en la visión de un tableau vivant descubierto por una cortina en alguno de los nichos o puertas de la fachada del teatro ${ }^{17}$. Se trata de un recurso abundante en el teatro del periodo, que responde a un mismo patrón, ya muestre una epifanía en comedias de santos, un cadáver en tragicomedias, un elemento especialmente llamativo del decorado como un

12 Montaigne, M. E.: Journal de voyage, ed. F. Rigolot, Paris, PUF, 2015, recurso electrónico.

13 Morales, A.: Viage de Ambrosio de Morales por orden del rey D. Phelipe II, a los reynos de Leon, y Galicia, y Principado de Asturias, para reconocer las reliquias de santos, sepulcros reales, y libros manuscritos de las cathedrales y monasterios, En Madrid, por Antonio Marin, 1765, pp. 79-80.

14 Glass, J.: The Royal Chapel of the Alcázar: Princely Spectacle in the Spanish Habsburg Court, Baltimore, John Hopkins University, 2004. Fernández-Santos Ortiz-Iribas, J.: “Ostensio regis: la 'Real Cortina' como espacio y manifestación del poder soberano de los Austrias españoles”, Potestas: Religión, poder y monarquía, 4 (2011), pp. 167-210.

15 Helmstutler Di Dio, K.: "The chief and perhaps only antiquarian in Spain. Pompeo Leoni and his collection in Madrid", Journal of the History of Collections, 18-2 (2006), pp. 137-167.

16 Roland Krischel, R.: "Cloths in and on paintings: from curtain to shutter and back again", en Costaras, N, y Young, C. (eds.), Setting the scene: European painted cloths from the fourteenth to the twenty-first century, Londres, Archetype Publications, 2013, pp. 1-10.

17 Ruano de la Haza, J.M., y Allen, J.J., Los teatros comerciales del siglo XVII y la escenificación de la comedia, Madrid, Castalia, 1994, pp. 449-460. 
altar, o una escena de reconocimiento o agnición. La definición más sintética de este fenómeno se encuentra en el Tesoro de la lengua castellana de Covarrubias: "Apariencias, son ciertas representaciones mudas que, corrida una cortina, se muestran al pueblo y luego se vuelven a cubrir"'18. El mismo lexicógrafo completa el panorama del desvelamiento en su definición de la cortina. Las acepciones que recoge, además de la de los "paramentos que cubren la cama", establecen una analogía entre los usos rituales y los usos teatrales del descubrimiento:

Los reyes acostumbran tener en sus capillas y en las iglesias donde oyen los oficios divinos unas camas, debajo de las cuales les ponen las sillas y sitiales; y porque se corre una de las cortinas, cuando entra o sale el rey, o se hace alguna ceremonia, como la confesión, la paz y las demás, el que tiene oficio de correr la cortina se llama sumiller de cortina, término alemán, al uso de la casa de Borgoña. En cierto género de representación muda, donde hacían aparencia de figuras calladas, tenían delante una cortina y esta la corrían para mostrarlas y después para volverlas a cubrir. La mesma cena de donde salen los representantes, se llamaba cerca de los romanos cortina. Y así correr la cortina sinifica algunas veces hacer demostración de algún caso maravilloso y otro de encubrirle, como también se hace en las tablas de pinturas ${ }^{19}$.

En su definición, Covarrubias sugiere que la expresión "correr la cortina" deriva de un conjunto de prácticas, en las cuales el desvelamiento sería un fenómeno análogo. Aplicado al romance apócrifo de Góngora, el desvelamiento sería figura de la verdad por llevar implícita una alusión a universos ceremoniales y a prácticas teatrales o de coleccionistas conocidas entre sus lectores, como las que acabamos de recopilar. ¿Hasta qué punto estas prácticas espectaculares tienen que ver con la "demostración de la maravilla" y con la revelación de una verdad? Como indica Covarrubias, el sentido figurado de la expresión "correr la cortina" está marcado por la ambigüedad entre lo patente y lo oculto. O bien indica la demostración de maravillas, o bien la disimulación de algún "caso" vergonzoso, como cuando hoy en día decimos que corremos un tupido velo. En el terreno de los ritos y los espectáculos, encontramos la misma ambigüedad, patente en ejemplos como el que a continuación apuntamos. En la tercera parte del Criticón de Gracián, el desvelamiento significa el descubrimiento de la verdadera naturaleza de la vejez, cuando se abren las cortinas del trono de Vejecia y queda patente su dualidad, pues la vejez son horrores y honores $^{20}$ : la verdad queda así al descubierto. Pero la misma escenografía también significa el desengaño del mundo, cuando un teatrero charlatán anuncia un gigante, pero "corrió una cortina y apareció un hombrecillo que aun encima de una grulla no se divisara" 21 . En definitiva, para Gracián, la dualidad entre verdad revelada y falsa apariencia separa radicalmente el protocolo real, incluso de una reina alegórica, del mundo de la farsa. Esta separación tan decorosa entre la alegoría de Vejecia y la falsedad del hombrecillo-gigante no oculta sin embargo el parecido formal de ambas revelaciones. De hecho, las "apariencias" teatrales contradicen, en su inmensa

\footnotetext{
Covarrubias, op. cit. (nota 4), p. 184.

Ibidem, pp. 619-620.

Gracián, B.: El Criticón, ed. S. Alonso, Madrid, Cátedra, 1980, pp. 561-562.

Ibidem, p. 629.
} 
mayoría, la idea gracianesca del desvelamiento como demostración de la mentira del teatro. La pobreza de sus usos cómicos lo prueba, de manera que el espectáculo descubierto por las cortinas de los teatros de corral es casi siempre serio, grave, maravilloso y venerable. Una aparición angélica o una epifanía milagrosa contrastan con los engañosos disfraces de los demonios de comedia, convertidos en falsos penitentes o mercaderes aviesos ${ }^{22}$. Los muertos de comedias históricas o tragicomedias son pruebas de que los furiosos hechos narrados se han llevado a cabo ${ }^{23}$. En cuanto a las escenografías fabulosas, nunca parecen más reales que cuando se descubren a ojos del público ${ }^{24}$. Uno de los mayores atractivos de la apariencia no es otro que el de parecer real.

A partir de la analogía trazada por Covarrubias, puede afirmarse que existen desvelamientos públicos y privados, ficticios y ceremoniales, litúrgicos y civiles, con pinturas y con actores, con reliquias y con imágenes, que respetan un patrón formal común. Aunque la interpretación del mismo depende, como en el Criticón, de su contexto en las esferas de la liturgia, el ceremonial real, el teatro y el coleccionismo de pintura, en todos los casos el espectáculo es igualmente digno y performativo. Basándome en las conclusiones de una tesis sobre este fenómeno del desvelamiento en el Siglo de Oro español ${ }^{25}$, propongo describir como "apariencia" (en el sentido de Covarrubias) este patrón espectacular. La "apariencia" es la puesta en escena por desvelamiento de un espectáculo asombroso, digno de reverencia y admiración, tanto más valioso cuanto que solo puede verse por unos instantes: activa y da vida a las imágenes, mientras convierte a los hombres en tableaux vivants, y constituye, al fin y al cabo, una técnica espectacular para proporcionarle aura a cualquier objeto ${ }^{26}$.

Gracias a tan nobles connotaciones, la sucesión entre ocultamiento y revelación propia del patrón espectacular de la "apariencia" constituye también un espectáculo del saber ${ }^{27}$. En un tiempo previo al divorcio entre la prueba científica y el régimen estético, es sobradamente conocido que "la puesta en escena de dispositivos heurísticos eficaces, basados en la sorpresa visual" 28 podía tener

22 En el desenlace de la Comedia de san Segundo de Lope de Vega, un demonio disfrazado de mujer penitente es vencido por una apariencia de Santiago, véase Comedia de san Segundo compuesta por Lope de Vega, BNE, MSS/14767, fols. 123r-147v, y especialmente fol. 144r.

23 En La cruel Casandra de Cristóbal de Virués, la protagonista anuncia, antes de morir: "En abriendo esas puertas, / sin duda, amigos fieles, / veréis de los hermanos y traidores / todas las muertes ciertas", tras lo cual la acotación indica: "Parecen en las dos puertas los muertos, como ha referido Casandra". Rey de Artieda, A., Virués, C. y Turia, R., Teatro clásico en Valencia I, ed. T. Ferrer, Madrid, Fundación José Antonio de Castro, 1997, pp. 206-208.

24 Como en la representación de El premio de la hermosura de Lope de Vega en Lerma, en 1614: "de la parte del río se oyeron grandes voces y ruido como de navegantes que se perdían, acudieron los salvajes a las peñas para reconocer lo que era, y corriéndose las cortinas que encubrían el río, pareció en él una nave que muy furiosa iba a enbestir con la roca, venían en ella Tisbe, Rosélida, Alizarán, Liriodoro y marineros con muchas luces; con ellas las personas que traían las joyas, vestidos y plumas. Fue la más agradable y nueva apariencia que pueda imaginarse, causando igualmente alegría y lástima, porque representaban con tanta propiedad su perdición, que parecía cierto el peligro del que se lamentaban", en Ferrer Valls, T.: Nobleza y espectáculo teatral (1535-1622). Estudio y documentos, Valencia, p. 252.

25 Ruiz Soto, H.: Apariencia ou l'instant du dévoilement. Théâtre et rituels dans l'Espagne du Siècle d'or, tesis de doctorado, Sorbonne Université, 2019.

26 Sobre el aura, véase Benjamin, W.: "La obra de arte en la época de su reproductibilidad técnica", ed. consultada Oeuvres, t. III, Paris, Gallimard, 2000.

27 Sobre la historia de esta idea, véase Hadot, P.: Le voile d'Isis, Paris, Gallimard, 2004.

28 Thébaud-Sorger, M.: "Spectacles de sciences", en Van Damme, S. (dir.), Histoire des sciences et des savoirs. De la Renaissance aux Lumières, Paris, Seuil, 2015, pp. 132-153, cit. p. 145. 
un valor demostrativo. En la definición de Covarrubias de la expresión "correr la cortina", 'demostrar' significa literalmente "declarar, manifestar, hacer patente" 29 . La apertura del velo no es más que la revelación de ese "caso maravilloso". Pero este sentido figurado de la expresión la convierte precisamente en una metáfora común del descubrimiento de un saber nuevo o de una verdad, como en el caso extremo de la verdad revelada ${ }^{30}$. Así ocurre también en los dos artefactos editoriales y tipográficos estudiados en este artículo: los frontispicios ilustrados y los desplegables didácticos. El desvelamiento adquiere en ambos un evidente valor epistemológico.

\section{Espectáculos del conocimiento: cortinas de papel y apariencias editoriales}

\section{El frontispicio con cortina: el mercado editorial de los descubrimientos}

Todo lo apuntado sobre la metáfora del descubrimiento como figura del aprendizaje permite observar con una mirada renovada algunos célebres frontispicios de la cultura bibliófila española y europea de los siglos XVI y XVII. Me refiero en especial a aquellos frontispicios que recurren a la representación de una cortina, ya sea como el lugar en el que se inscribe el título, ya sea como un elemento de decoración, por ejemplo un paño de honor o unos velos corridos en lo alto. Abundan los frontispicios en forma de retablo o pórtico, con unos putti encaramados al frontón sosteniendo una cartela en forma de velo o cortina. Al incorporar el título en la cortina, impresores y grabadores prometen revelaciones y hacen de la lectura un espectáculo que se despliega al abrir la página del frontis, levantando literalmente el velo que cubre la obra. Apelando así a la curiosidad del lector, establecen un vínculo estrecho entre la hermosura del libro y el conocimiento que este promete. La maravilla se convierte en un argumento de venta destinado a atraer al público. El siguiente repaso de algunos de estos frontispicios no pretende ser exhaustivo: el comentario de unos pocos ejemplos servirá para exponer las connotaciones asociadas a esta fórmula iconográfica ${ }^{31}$.

Covarrubias, op. cit. (nota 4), sv. 'demostrar'.

Véase Bord, L. J., Debiais, V. y Palazzo, E.: Le rideau, le voile et le dévoilement: du Proche-Orient ancien à l'Occident médiéval, Paris, Geuthner, 2019.

31 Véase al respecto también Ruiz Soto, op. cit. (nota 25), pp. 135-145. 


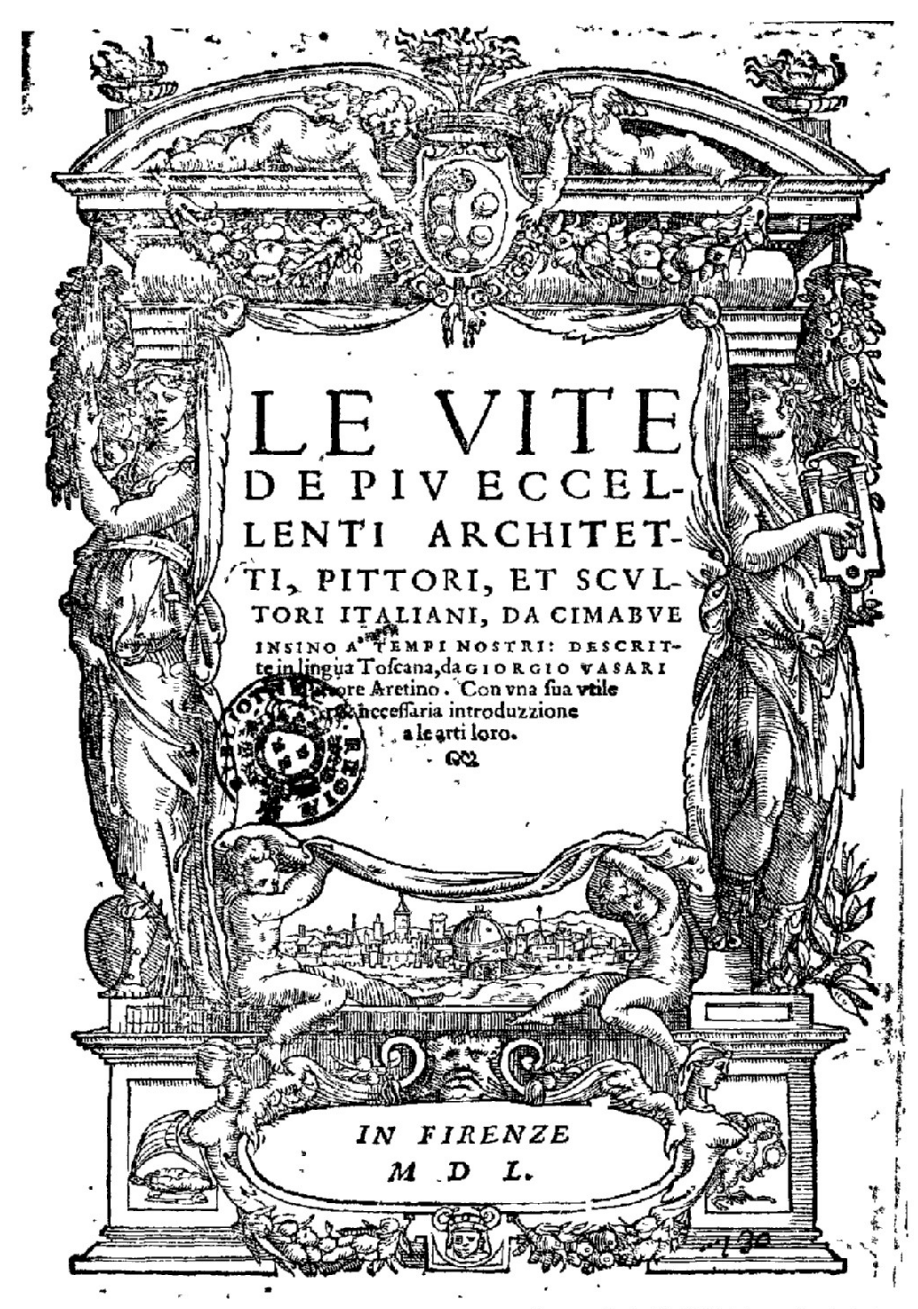

Figura 1. Giorgio Vasari, frontispicio de Giorgio Vasari, Le vite de più eccellenti architetti, pittori et scultori italiani, da Cimabue insino a tempi nostri, descritte in lingua toscana, da Giorgio Vasari,... Con una sua utile... introduzzione a le arti loro, 2 vol., Firenze, L. Torrentino, 1550, Bibliothèque Nationale de France, RES-K-734.

El frontispicio en el que el título aparece en un velo parcialmente alzado, por el que asoma un emblema del libro, es el que retoma de forma más patente el sistema de la "apariencia". En 1550, el frontispicio de la primera edición de las Vite... de Vasa$\mathrm{ri}^{32}$, compuesto por el propio autor, presenta dos putti que levantan una cortina, descubriendo así un paisaje ideal: una ciudad que mezcla Roma con Florencia ${ }^{33}$ (Figura 1). Esta ciudad representa el horizonte teórico de la lectura ${ }^{34}$, ya que en esta primera

32 Vasari, G.: Le vite de più eccellenti architetti, pittori et scultori italiani, Florencia, L. Torrentino, 1550.

33 Simonetti, C.M.: La vita delle "Vite" vasariane: profilo storico di due edizioni, Florencia, Olschki, 2005, p. $49-51$.

34 Sobre esta metáfora de la lectura como un camino, Bouza, F.: Hétérographies: formes de l'écrit au Siècle d'or espagnol, Madrid, Casa de Velázquez, 2010, p. 121. 
versión el libro se cierra con la vida de Miguel Ángel, el florentino que reinó sobre el arte romano. El dispositivo editorial se basa por tanto en la equivalencia metafórica del libro y de la imagen descubierta, como un emblema o una imagen mnemotécni$\mathrm{ca}^{35}$ del conjunto. En Venecia, Daniele Barbaro emplea un frontispicio semejante para su edición de 1584 de la arquitectura de Vitruvio: I dieci libri della 'architettura di $M$. Vitruuio tradotti et commentati... ${ }^{36}$ (fol. ${ }^{*} 1 \mathrm{r}$ ). En este caso, el título también se inscribe en la imagen de una tela, que un mascarón sostiene a media altura del frontispicio. Detrás o debajo de este velo se encuentra la alegoría all'antica de un río rodeado de emblemas de poder terrenal y religioso, y de instrumentos arquitectónicos, delante de un paisaje con algunas construcciones características de la arquitectura antigua: varias columnas y templos, una pirámide de Cestio y algunas ruinas. Tal sería la arquitectura: una ciencia con su instrumental geométrico, un atributo del poder como las coronas y las mitras, y una garantía del renacimiento de la antigüedad. En el siglo XVII, la misma tipología de frontispicios se repite en obras como el Tesoro de la farmacopea de Indias de Francisco Hernández: Rerum medicarum Nouae Hispaniae thesaurus seu Plantarum animalium mineralium mexicanorum historia ${ }^{37}$ (Figura 2). En este caso, el velo descubre un mapa de México, origen de los nuevos remedios, de modo que al saber médico se suma la imagen geográfica. En la república sagrada de las letras, el modelo se encuentra por ejemplo en la Reforma de los Descalzos de Nuestra Señora del Carmen de la primitiva Observancia hecha por Santa Teresa de Jesús de Francisco de Santa María ${ }^{38}$ (1644): el título aparece inscrito en un velo que san Elías y santa Teresa sostienen con una mano mientras con otra señalan el monte Carmelo, como si acabaran de descubrirlo a ojos del lector, a los pies de una Virgen con el niño. Algo semejante ocurre en el frontispicio de los China monumentis de Athanasius $\operatorname{Kircher}^{39}$ (1667): en lugar del título, desplazado a la portadilla en el folio siguiente, el velo sostenido por un putto muestra un mapa de China (Figura 3), cifra de todo el libro y de sus abundantes ilustraciones, empezando por las dos primeras, que son otros dos mapas ${ }^{40}$. Por su tamaño, sin embargo, este velo parece haber sido descolgado por el angelote que lo sostiene desde un cielo en el que se descubre, en un rompimiento de gloria, el monograma IHS. El descubrimiento celestial de este frontispicio presenta el libro como un resumen de la aspiración universal del proselitismo jesuita: el saber del libro aparece cifrado en el mapa, que a su vez desvela la gloria a la que aspiran, por el conocimiento, los jesuitas. Se trata por tanto de una

35 Bolzoni, Lina, La chambre de la mémoire, Ginebra, Droz, 2005, pp. 333-343.

36 Barbaro, D.: I dieci libri della'architettura di M. Vitruuio, In Venetia, Apresso Francesco de' Franceschi senese, 1584.

37 Hernández, F.: Rerum medicarum novae Hispaniae thesaurus, seu Plantarum, animalium, mineralium mexicanorum historia, ex Francisci Hernandez,... relationibus in ipsa mexicana urbe conscriptis a Nardo Antonio Reccho,... collecta ac in ordinem digesta a Joanne Terrentio,... notis illustrata, Romae, ex. typ. V. Mascardi, 1649, reed. 1651. Véase también Freedberg, D.: The Eye of the Lynx, Chicago, University of Chicago Press, 2002, pp. 267-272 y Pimentel, J.: Fantasmas de la ciencia española, Madrid, Marcial Pons, 2020, pp. 51-95.

38 Santa María, F.: Reforma de los Descalzos de Nuestra Señora del Carmen de la primitiva Observancia hecha por Santa Teresa de Jesús, En Madrid, por Diego Diaz de la Carrera, 1644. Véase https://bibliotecadigital.jcyl. es/es/consulta/registro.cmd?id=16560 [Consulta: 20 de junio de 2020].

39 Kircher, A.: Athanasii Kircheri e Soc. Iesu China monumentis qua sacris qua profanis, nec non variis naturae \& artis spectaculis, aliarumque rerum memorabilium argumentis illustrata, Amstelodami, apud Joannem Janssonium à Waesberge \& Elizeum Weyerstraet, 1667. Véase http://bdh-rd.bne.es/viewer.vm?id=0000223429\&page $=1$ [Consulta: 20 de junio de 2020].

40 Ibidem, láminas 1 y 2. 
reivindicación para la religión católica del imperio chino "in ultimis illus terrarum

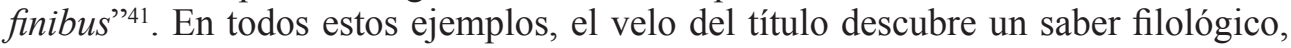
histórico o pictórico, arquitectónico o médico, geográfico o antropológico, religioso o misional, demostrando así el potencial de este tipo de frontispicios para poner en valor libros de curiosidad, ciencia y erudición mediante una teatralización emblemática y mnemotécnica de su contenido.

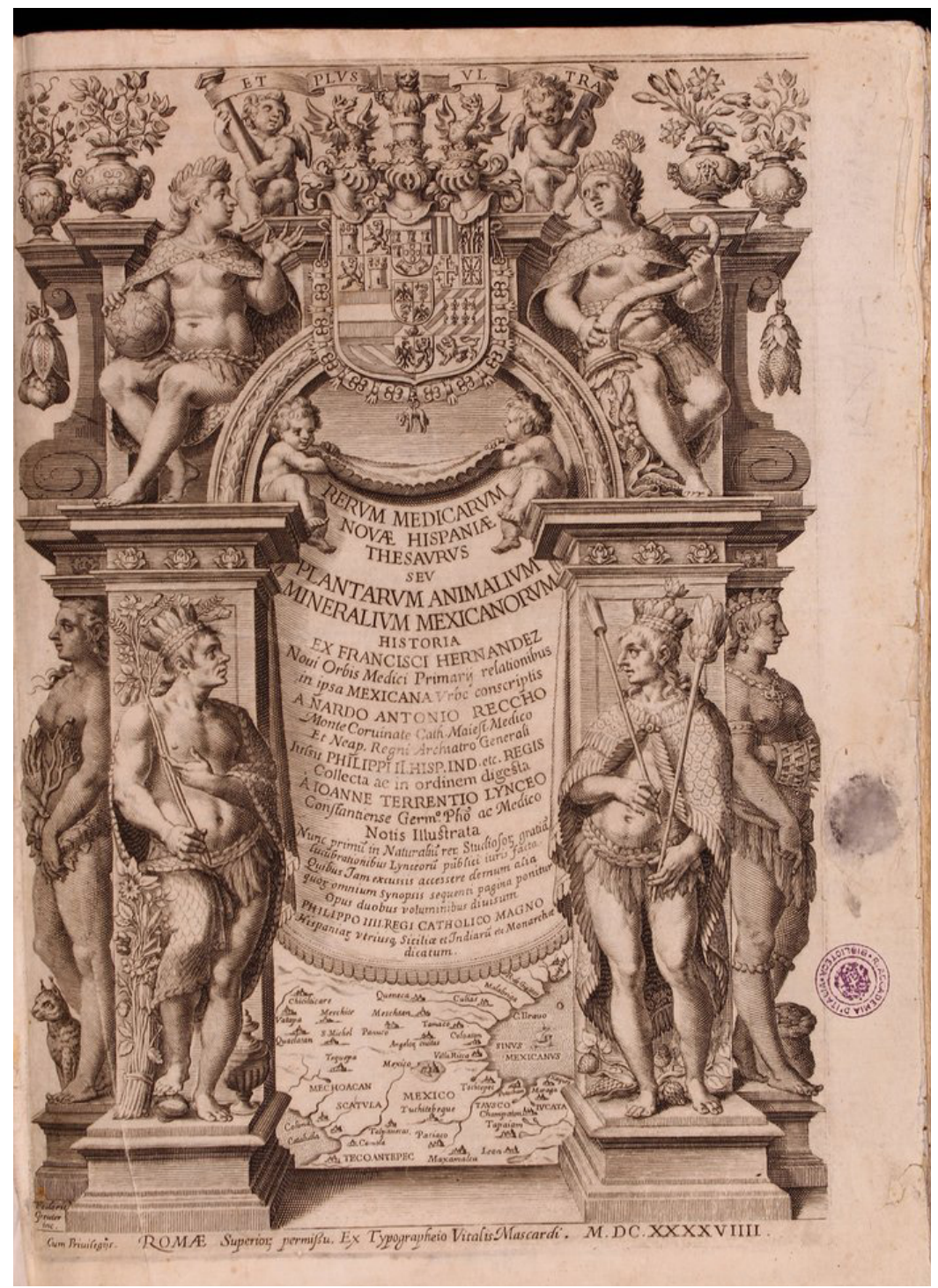

Figura 2. Johan Friedrich Greuter, frontispicio de Francisco Hernández, Rerum medicarum novae Hispaniae thesaurus, seu Plantarum, animalium, mineralium mexicanorum historia, ex Francisci Hernandez,... relationibus in ipsa mexicana urbe conscriptis a Nardo Antonio Reccho,... collecta ac in ordinem digesta a Joanne Terrentio,... notis illustrata, Romae, ex typ. V. Mascardi, 1649.

$41 \quad$ Ibidem, fol. **1r. 


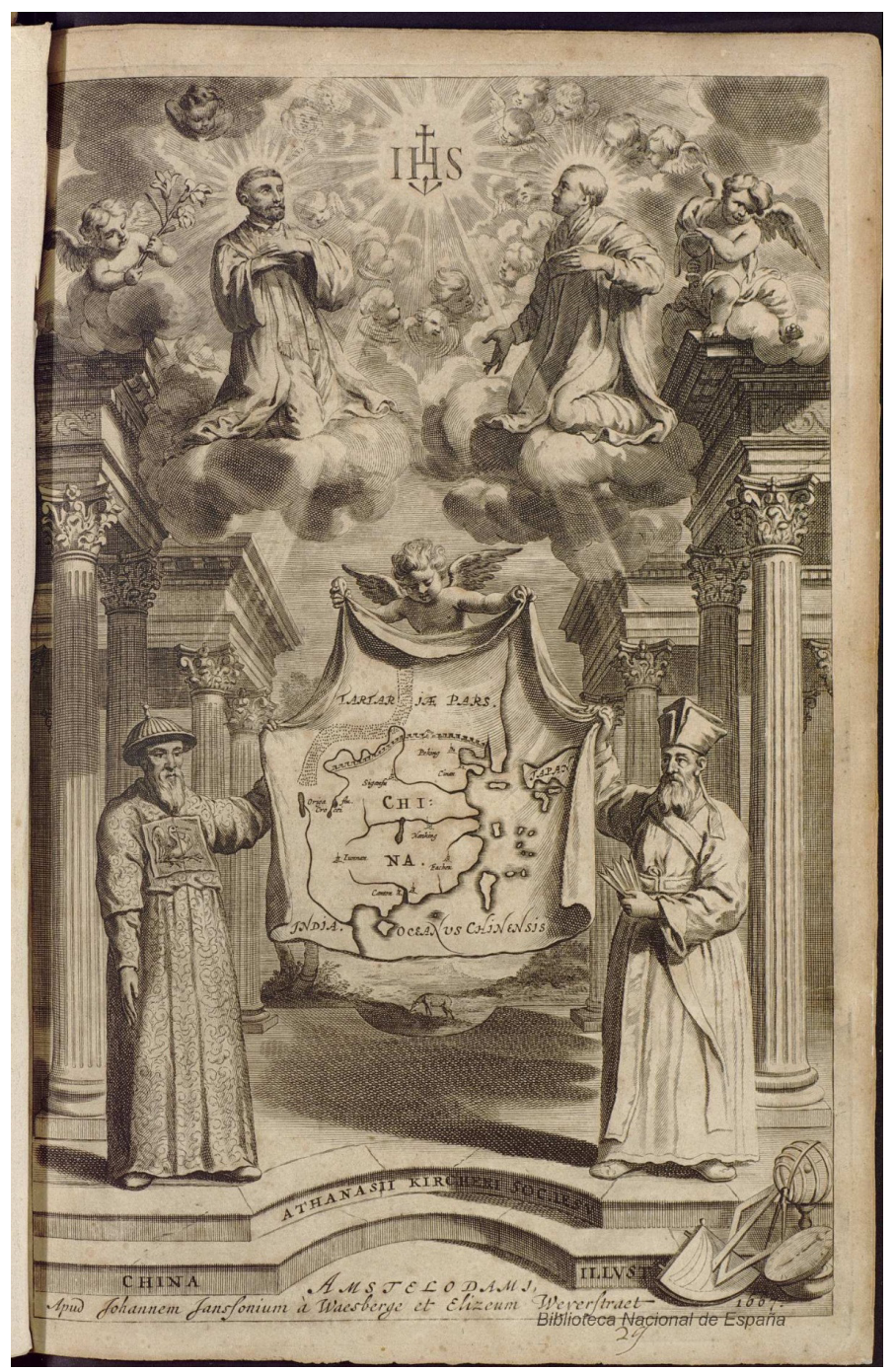

Figura 3. Frontispicio de Athanasius Kircher, Athanasii Kircheri e Soc. Iesu China monumentis qua sacris qua profanis, nec non variis naturae \& artis spectaculis, aliarumque rerum memorabilium argumentis illustrata, Amstelodami, apud Joannem Janssonium à Waesberge \& Elizeum Weyerstraet, 1667, BNE, ER/2094.

Otro tipo de frontispicio que apela, indirectamente, a una puesta en escena similar, es el que se presenta como 'ya descubierto', mediante la incorporación de un velo como adorno lateral o superior, ya levantado y abierto. Es el caso de alguno de los frontispicios de la obra de Serlio: Libro primo [-quinto] d'architettura di Sebastiano Serlio bolognese... ${ }^{42}$. Cada libro presenta un frontispicio distinto: en el

42 Serlio, S.: Libro primo [-quinto] d'architettura di Sebastiano Serlio bolognese, nel quale con facile \& breue modo si tratta de primi principij della geometría. Con nuoua aggiunta delle misure che seruono a tutti gli ordini de componimenti, che ui si contengono, In Venetia, Appresso Francesco Senese, \& Zuane Krugher Alemanno, compagni, 1566. 
primero (fol. A1r), dos putti apartan un cortinaje del que solo se ven precisamente los pliegues en los márgenes laterales, sugiriendo que acaban de retirar el velo que cubría la página. Este recuerdo marginal de un descubrimiento teatraliza el frontispicio como la revelación de un saber oculto ${ }^{43}$ : las alegorías visuales se multiplican para afianzar la metáfora del desvelamiento. Así, por ejemplo, el saber oculto de los Sátiros o Silenos toma cuerpo en Lisboa, en las prensas de Luis Rodríguez, que imprime en 1541 les Medidas del romano de Diego Sagredo, en cuyo frontispicio encontramos a estos personajes - conocedores de lo arcano- reteniendo las cortinas que dos ángeles están abriendo ${ }^{44}$ (Figura 4). El frontispicio de Sagredo se repite exactamente en al menos otros dos impresos, en Sevilla y en Venecia ${ }^{45}$. De hecho, el éxito de este modelo de frontispicio con cortina lateral es rotundo, desde el Libro del misurar con la vista de Silvio Belli ${ }^{46}$ hasta los Diálogos de la pintura de Carducho $^{47}$ (Figura 5). Las características cinéticas de la cortina lateral han de ser comprendidas en todos estos ejemplos en relación con el pórtico arquitectónico que ostentan, como si de un retablo se tratase. Tratando de libros y de retablos, fray Diego de la Vega nos indica cómo interpretar esta estrategia editorial en un sermón de su Paraíso de la gloria de los santos, en el comentario de un salmo cuyo establecimiento textual recogía una variante entre la piel y la cortina $(103,2$ : "extendens caelos ut pellem / cortinam"):

Antiguamente, como no había papel, solían escribir en pieles de animales como ahora en pergaminos, y de la misma suerte que ahora se descoge un pergamino y se abre un libro para leer en él y ver allí lo que queremos saber, así entonces se descogía y desplegaba la piel, para ver lo que en ella estaba pintado y escrito. "Ah señor", dice David, "que habéis extendido a nuestros ojos esos cielos como si fueran pieles y unos riquísimos libros, iluminados de oro y azul para que por ellos vengamos en vuestro conocimiento y, por su rara hermosura, saquemos la de su hacedor". Félix [Pratensis] vuelve aquí: "extendens caelum sicut cortinam": "Estendistes el cielo como cortina'. Por la riqueza y curiosidad de la cortina solemos sacar la del retablo que encubre. Entráis en la capilla real, o en otra cualquiera iglesia, veis el retablo cubierto con una rica cortina, pintada de una mano muy prima, y luego decís: “¡Oh qué admirable debe ser este retablo!”. iQuién hay que levante los ojos, cristianos, a esa hermosa cortina del cielo, pintada de tantos luceros y estrellas, adornados de tantos primores, con sus ricos bordados de luz, que no rompa

43 El mismo frontispicio se repite en la edición suelta de Serlio, S.: Libro estraordinario di Sebastiano Serlio Bolognese nel quale si dimostrano trenta porte di opera rustica mista con diuersi ordini, In Venetia, Appresso Francesco Senese, \& Zuane Krugher Alemanno, compagni, 1566. Véase http://bdh-rd.bne.es/viewer.vm?i$\mathrm{d}=0000231696 \&$ page $=5$ [Consulta: 20 de junio de 2020].

44 Sagredo, D.: Medidas d[e]l romano: agora nueuamente impressas y añadidas de muchas pieças y figuras muy necessarias a los officiales que quieren seguir las formaciones de las basas, colunnas, capiteles y otras pieças de los edificios antiguos, Lisbona, imprimido por Luis Rodriguez..., 1541. Véase, sobre el saber silénico, Lavocat, F.: La Syrinx au bûcher: Pan et les satyres à la Renaissance et à l'âge baroque, Paris, Droz, 2005, pp. 26-27.

45 Ginés de Sepúlveda, J.: El Diálogo llamado Demócrates, Sevilla, Juan Cromberger, 1541 y Ruscelli, G.: De' secreti del reverendo donno Alessio piemontese, Venecia, appresso Domenico Farri, 1570.

46 Belli, S.: Libro del misurar con la vista, Venecia, Giordano Ziletti, 1569. https://archive.org/details/ARes10516/ page/n5/mode/2up.

47 Carducho, V.: Diálogos de la pintura, Madrid, Francisco Martínez, 1634. En una alegoría dentro del volumen, fol. 83 r, una cortina levantada descubre el lienzo en el que la pintura plasma su obra: http://bdh-rd.bne.es/ viewer.vm?id=0000034318\&page $=169$ [Consulta: 20 de junio de 2020]. 
en admiración diciendo "Ah, Señor, si tan hermosa es la cortina de fuera, cuál será el retablo y la imaginería que encierra dentro de sí...”!48.

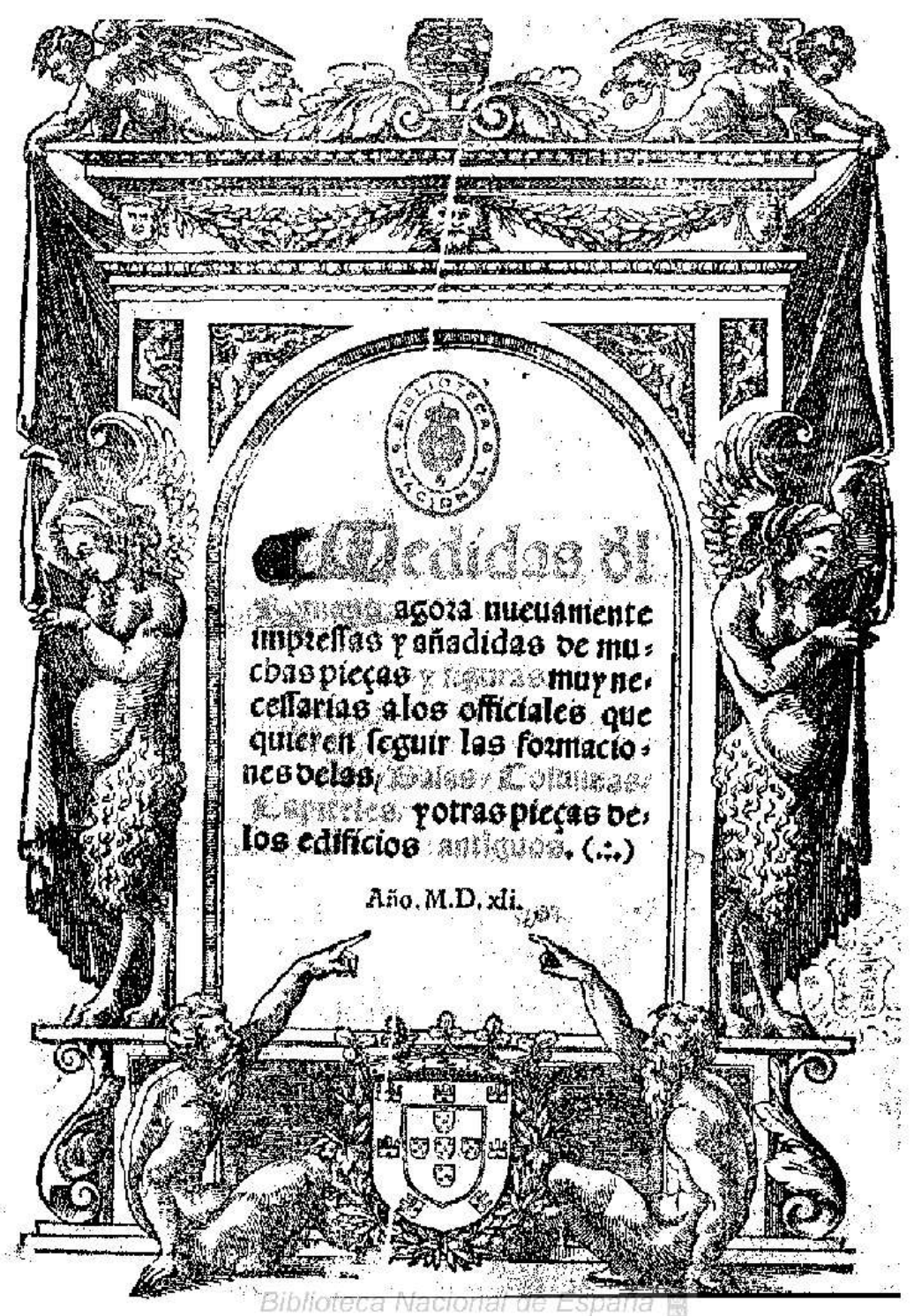

Figura 4. Diego de Sagredo, frontispicio de Diego de Sagredo, Medidas d[e]l romano: agora nueuamente impressas y añadidas de muchas pieças y figuras muy necessarias a los officiales que quieren seguir las formaciones delas basas, colunnas, capiteles y otras pieças de los edificios antiguos, Lisbona, imprimido por Luis Rodriguez..., 1541, BNE, R/3222.

4 "En la fiesta de la Santísima Trinidad", Vega, D.: Parayso de la gloria de los santos donde se trata de sus prerogatiuas y excelencias, tomo primero, Barcelona, en la Emprenta de Gabriel Graells y Giraldo Dotil, 1604, p. 402 . 


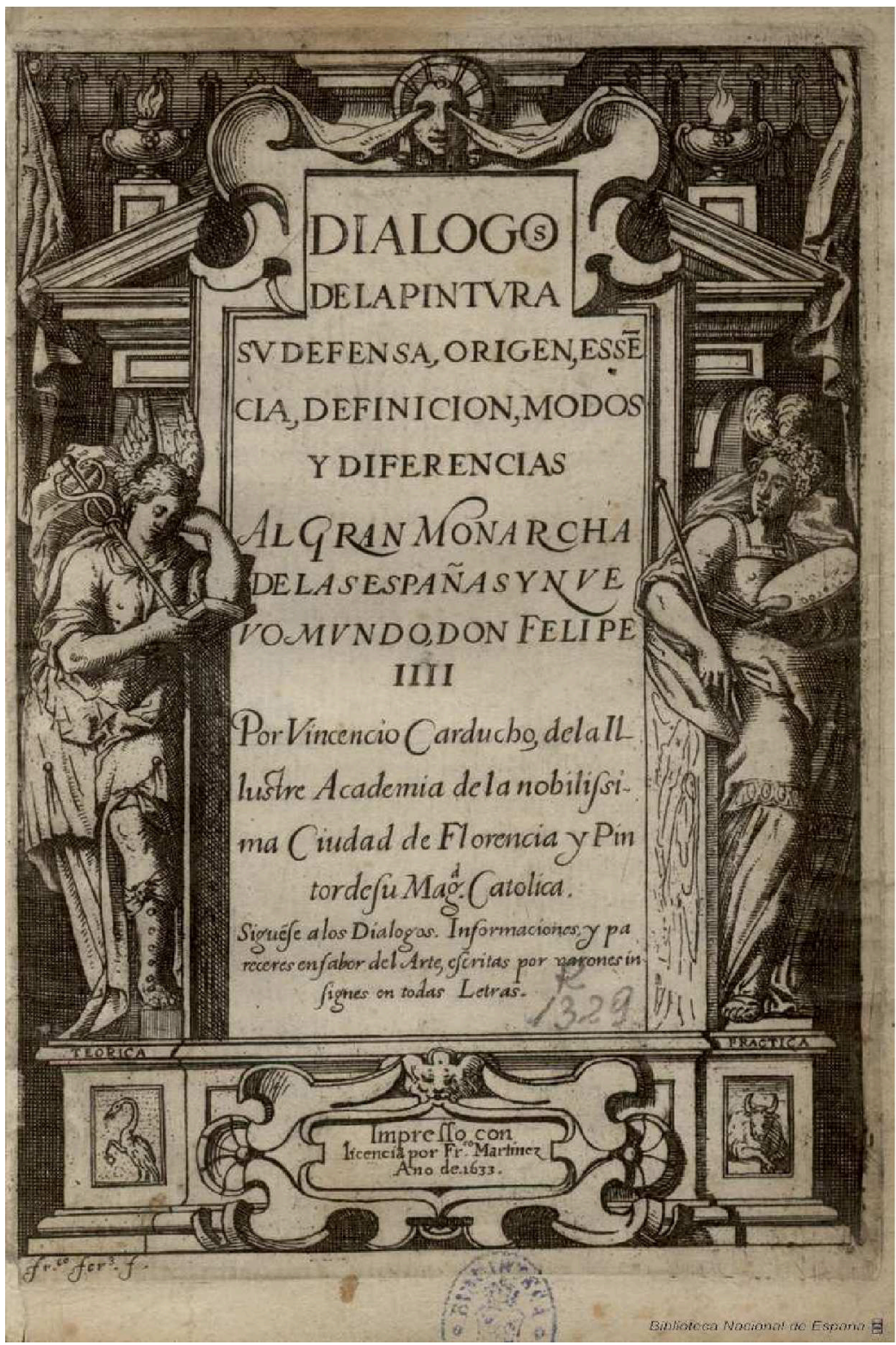

Figura 5. Francisco Fernández, frontispicio de Vicente Carducho, Diálogos de la pintura, su defensa, origen, essencia, definicion, modos y diferencias..., en Madrid, impreso con licencia por Francisco Martínez, año de 1633 (1634), BNE, R/1329.

Comentando tanto la lección mayoritaria del salmo como la defendida por Félix de Prato en su traducción del hebreo, Diego de la Vega no solo glosa la figura veterotestamentaria. También comenta, equiparándolos, el espectáculo de la apariencia litúrgica y el de la apertura de un libro. Según indica el predicador, el proceso del descubrimiento construye el suspense o el deseo de ver, aumentando así la "curiosidad" del espectador ante la gradación in crescendo de la maravilla, de la "hermosura" y de la "admiración": lo descubierto siempre supera a la cortina que lo cubre. Del mismo modo que la 
riqueza y la hermosura del libro anuncian el "conocimiento" que contiene, la calidad de la cortina indica lo admirable del retablo. Algo semejante ocurre con las puertas churriguerescas donde se "petrifica[n] las cortinas de tela de las fiestas"49. Este modelo interpretativo, válido tanto para la apertura de un libro como para el descubrimiento litúrgico, nos obliga a atender a la importancia de las cortinas en infinidad de frontispicios. Ya sean velos inmóviles, como el que Serlio emplea para el título del segundo libro de su Arquitectura ${ }^{50}$, ya sean cortinajes levantados, como en la parte superior del frontispicio de la Nueva idea de la tragedia antigua de José Antonio González de Salas $^{51}$, estas cortinas son ante todo un elemento cinético. Levantados o por levantar, estos velos sugieren, con sus pliegues y su dinamismo, el valor de lo que el lector descubre, como si revelara un saber oculto cuando abre un impreso autorizado ${ }^{52}$.

En su versión más ingeniosa, esta escenografía puede desdoblarse en un sistema de imágenes yuxtapuestas en varios folios, para adaptarse así a la forma del libro y al gesto de la lectura, convirtiéndola en un espectáculo en el que la página-cortina descubre literalmente el resto de la obra. Aparte del segundo libro serliano, baste mencionar dos frontispicios de este tipo. El primero pertenece a la Pompa Funeral, Honras y Exequias en la muerte de la muy alta y Católica Señora doña Isabel de Borbón ${ }^{53}$ (1645), ilustrado por Pedro de Villafranca. En este libro, el título se encuentra inscrito en una cartela que dos esqueletos, figuras de la muerte, sostienen como una cortina ante un pórtico. El folio siguiente, plegado en varios ejemplares debido a su gran tamaño, muestra el retrato fiel de la reina fallecida: detrás de la cortina de la muerte, sobrevive, en el retrato, su memoria, que el resto del impreso honra con la relación de las exequias. El segundo ejemplo podría ser la Anatomia de Thomas Bartholin, publicada en Leiden por François Hackius en 1651 y en la Haya, en 1655, por Adriaan Vlacq. El frontispicio (fol. * $1 \mathrm{r}$ en ambas ediciones) representa una piel humana, sobre la que se inscribe el título del libro. Detrás de esta cortina anatómica, el lector descubre el texto "cum iconibus novis accuratissimis"54: una revisión "exactísima" de la iconografía anatómica debatida en toda Europa, con el añadido del sistema linfático descubierto por Bartholin ${ }^{55}$. Este frontispicio confirma así la metáfora de Jusepe Martínez: la anatomía "es la mano -digámoslo así- que corre la cortina de la carne al hueso para dejarle patente a nuestros ojos» ${ }^{56}$. Ambos ejemplos llevan hasta sus últimas consecuencias la escenografía editorial del frontispicio descubierto. Por la truculencia de las

\footnotetext{
Gállego, J.: Visión y símbolos en la pintura española del Siglo de Oro, Madrid, Aguilar, 1972, p. 133.

Serlio, op. cit. (nota 42), fol. $17 \mathrm{r}$ o E1r.

51 González de Salas, J. A.: Nueva idea de la tragedia antigua o Ilustración última al libro singular de Poética de Aristóteles Stagirita, Madrid, Francisco Martínez, 1633.

52 Bouza, F.: "Dásele licencia y privilegio". Don Quijote y la aprobación de libros en el Siglo de Oro, Madrid, Akal, 2012.

53 Pompa Funeral, Honras y Exequias en la muerte de la muy alta y Católica Señora Doña Isabel de Borbon, Reyna de las Españas y del Nuevo Mundo que se celebraron en el... Convento de S. Geronimo de Madrid, [s.1.] Madrid, [s.n.] Diego Díaz de la Carrera, 1645.

54 Bartholin, T.: Thomae Bartholini Casp. F. Anatomia ex Caspari Bartholini, parentis institutionibus, omniumque recentiorum et propriis observationibus Reformata cum iconibus novis accuratissimis, Lugduni Batavorum, Ex officina Francisci Hackii, 1651, fol. *2r.

55 Sobre el debate en torno a las imágenes anatómicas, Mandresi, R.: "Le regard scientifique : cultures visuelles des sciences", en Van Damme, op. cit. (nota 28), p. 230-253.

56 Martínez, J.: Discursos practicables del nobilisimo arte de la pintura, ed. M. E. Manrique Ara, Zaragoza, Huesca y Teruel, Prensas Universitarias de Zaragoza, Instituto de Estudios Altoaragoneses e Instituto de Estudios Turolenses, 2008, p. 29.
} 
dos imágenes, por su adecuación a la materia, por la ingeniosidad e interactividad de su escenografía, estas "apariencias” editoriales son verdaderos símbolos mnemotécnicos de ambos libros. Así pues, estos frontispicios le dan cuerpo, movimiento y contenido a la metáfora según la cual "correr la cortina" significa "hacer demostración de algún caso maravilloso": una metáfora que impresores, grabadores y autores emplearon en toda Europa para engalanar sus libros con el atractivo del saber arcano.

\section{Leer y revelar imágenes: el descubrimiento como activación del saber y la temporalidad de la apariencia}

Por su capacidad para demostrar maravillas, la cortina de apariencias es capaz de poner en escena el saber y su adquisición de manera que parezca arcano y enigmático, y por ello más valioso. El proceso de desvelamiento en sí mismo implica la resolución de un enigma, en una construcción temporal peculiar para este espectáculo del conocimiento: el instante de la revelación basa el proceso de aprendizaje en la sorpresa y el cambio de visibilidad. Además de los frontispicios, otra "escenografía tipográfica" ${ }^{57}$ lleva hasta sus últimas consecuencias la metáfora del desvelamiento: la Navegación para el cielo o Carta del cartujo.

Este curioso impreso es un extraordinario ejemplo de lo que Víctor Infantes llamó "literatura gráfica del juego" 58 . Se trata de un poema ilustrado, de contenido moral y religioso, del que se conocen varias ediciones, con variantes de poca sustancia en los adornos y los grabados ${ }^{59}$. En todos los casos, se presenta como un librillo doblado en cinco pliegues, que descubre sucesivamente varios formatos al abrirse ${ }^{60}$. En origen, está

57 Osuna, I. e Infantes, V.: "Paredes de versos dibujadas. Fábrica y materia del cartel poético barroco (16501700)", Bulletin hispanique, 113-1 (2011), p. 173.

58 Infantes, V.: "Ludo ergo sum. La literatura gráfica del juego áureo", en Bègue, A. y Herrán Alonso, E. (dirs.), Pictavia Aurea. Actas del IX Congreso de la Asociación Internacional "Siglo de Oro", Toulouse, Presses Universitaires du Midi, 2014a, pp. 35-55, esp. p. 48. Véase también: Infantes, V.: Ludo ergo sum. La literatura gráfica del juego áureo, Madrid, Turpin Editores, 2014b, pp. 43-47 y Lyra mixta. Silva ejemplar de artificios gráfico-literarios, Madrid, Turpin Editores, 2015, pp. 415-418. Por último, es de obligada consulta Karr Schmidt, S.: Interactive and Sculptural Printmaking in the Renaissance, Leiden, Brill, 2018.

59 La edición príncipe es de Barcelona, por Joseph Llopis, a la calle de S. Domingo, 1688. Se encuentra reproducida en Ortiz García, J.A. y Costa, N., "Papiroflexia espiritual", Mesa revuelta: el diario de Studiolum [en línea], 5 de enero de 2011, http://mesa-revuelta.blogspot.com/2011/01/papiroflexia-espiritual.html [Consulta: 20 de junio de 2020] y en Infantes, V.: Ludo ergo sum y Lyra mixta, op. cit. (nota 58, 2014b y 2015). Está conservada en el Archivo Histórico de la Ciudad de Barcelona, F-34-C1/48 (320x425 mm). El balance de reediciones establecido por Víctor Infantes en su Lyra mixta, pp. 415-416, y reproducido en el blog de Studiolum, incluye entre otras la de Barcelona, por Juan Centené y Juan Serra, ca. 1796, Biblioteca de Catalunya (BC), II (i).2 B R.E. 28165; la de Valencia, por Francisco Burguete, s.a. (ca. 1768-1773, reproducida en Botrel, J. F., "Sur les usages de l'imprimé. La Navegación para el cielo ou le jeu du chartreux", en Moner, M. y Clément, J.P., Hommage des hispanistas français à Henry Boneville, Tours, Societé des Hispanistes Français de 1'Enseignement Supérieur, 1966, pp. 59-74) o la de Barcelona, Juan Piferrer, 1735, estudiada por Galindo, E., "Esfuerzo y desapego en la navegación para el cielo, un pasatiempo religioso del siglo XVIII", Scripta Nova, Revista Electrónica de Geografia y Ciencias Sociales, 6-119 (2002), http://www.ub.es/geocrit/sn/sn119-20.htm [Consulta: 20 de junio de 2020]. Además de las mencionadas por Infantes, cabe añadir las siguientes: en Manresa, por Ignacio Abadal, ca. 1800, BC, II (i).2 BC 1; en Sevilla, por Aragón y Compañía, en 1816, BNE, R/35383(12), y en Madrid, por J. M. Marés, 1848, BNE, U/11169(108). Las variantes incluyen diferencias en los adornos (filetes y culs-delampe), en la factura de los grabados y en la presencia o la ausencia de la Virgen, san Juan y los dos ladrones en la imagen de la Crucifixión.

60 En la edición valenciana de Francisco Burguete, respectivamente 7 x 7, 7 x 15, 7 x 30, 13,5 x 30 y 21 x $30 \mathrm{~cm}$ (Botrel, op. cit, pp. 60 y 65). La edición príncipe es algo mayor, pues pasa de 71 x $80 \mathrm{~mm}$. a 320 x $425 \mathrm{~mm}$.: 
pensado como una hoja en doble folio, "distribuida en calles horizontales con diferentes direcciones de composición" "61, con tipos, adornos y grabados dispuestos de manera especialmente ingeniosa. Las treinta y una redondillas, cinco cuartetas y dos décimas del texto están organizadas en unidades de sentido, subrayadas en algunas ediciones por las orlas de filetes que ordenan la lectura. Dentro de esas orlas, la numeración de las estrofas guía al lector del número 2 al 34, con las cinco cuartetas agrupadas bajo el número 5 . Así se desvelan distintas imágenes comentadas en lo que Jean-François Botrel llamó "tipogramas", pensando en los fotogramas de una película ${ }^{62}$. Sin duda la comparación es acertada, habida cuenta del carácter dinámico, casi cinético, del "ceremonial de la lectura" ${ }^{63}$ propio de este curioso espectáculo iconográfico y textual.

En el proceso del descubrimiento, aparecen cinco tipogramas, que corresponden en cada caso a un formato y a una idea. Ilustrados todos ellos, salvo el primero, aparecen en cada uno de los despliegues de la Carta (Figura 5, Figura 6, Figura 7, Figura 8, Figura , Figura 10). El primero, correspondiente al librillo inicial con vuelto y recto $^{64}$, sería el paratexto, con el título, los datos de impresión, y dos primeras redondillas, la primera sin numerar: "A todo mortal escribe / aquesta carta un cartujo / y da en ella un fiel dibujo / que muerte y vida describe". El segundo tipograma descubre, una vez abierto el primer pliegue, un mundo grabado y otras dos redondillas (n. 3-4) sobre el tema de la vanidad terrenal: para seguir la lectura, las dos mitades del grabado se separan como las puertas de un tríptico, y así "se indica que el hombre debe desprenderse del mundo para descubrir la revelación de Dios" "65. El tercer tipograma se muestra así, en una sola calle pero ya con el formato de la plana a lo largo, encabezado con un grabado de la Crucifixión. Debajo de esta imagen, una glosa de cinco cuartetas (n. 5) apela a la conversión del lector, solicitada por el propio Cristo. En el mismo tipograma, otra redondilla (n. 6) apela al desengaño de las pompas humanas. El cuarto tipograma muestra precisamente estas pompas: a la izquierda de una vela, "reloj" de la vida, aparece el grabado de un rey; a la derecha el de una dama con sus mejores galas. Estas dos figuras le hablan al lector en primera persona en las redondillas 7 y 16 respectivamente, dispuestas sobre ambas figuras dentro de una orla de filetes. A sus pies, las redondillas 8 a 11 a la izquierda, y 17 a 20 a la derecha son las glosas del Cartujo sobre este rey y esta dama. Entre estas redondillas y alrededor de la vela, las redondillas 12 a 15 animan al lector al desengaño. El último tipograma es precisamente el desengaño, pues se descubre al abrir del todo la plana, despojando de sus ricos ropajes a las dos figuras y mostrando en el centro, bajo la vela, un retrato de san Bruno. Debajo del rey convertido en pastor miserable, y debajo de la dama transformada en muerte, las redondillas 21 a 24 y 25 a 28 recogen sus discursos desengañados. En el centro de la plana, dos décimas, 29 y 30, y las cuatro últimas redondillas, alrededor de la figura de san Bruno, muestran que este es el Cartujo a quien hay que atribuir tan devota lección.

Osuna e Infantes, op. cit. (nota 57), p. 177. Como curiosidad, la Bibliothèque Nationale de France conserva un ejemplar, perteneciente a un cuaderno de "Romances, canciones imp. à Cordoue par Rodriguez" y por tanto impreso en Córdoba por Rafael Rodríguez (s. a.), en el que el anverso y el reverso están separados y plegados por la mitad para ser encuadernados y leídos como libro: BNF, YG-1933 e YG-1934.

61 Infantes, “Ludo ergo sum. La literatura gráfica del juego áureo”, op. cit. (nota 58, 2014a), p. 48.

62 Botrel, op. cit. (nota 59), p. 65.

63 Osuna e Infantes, op. cit. (nota 57), p. 176.

64 En ese orden.

65 Galindo, op. cit. (nota 59). 

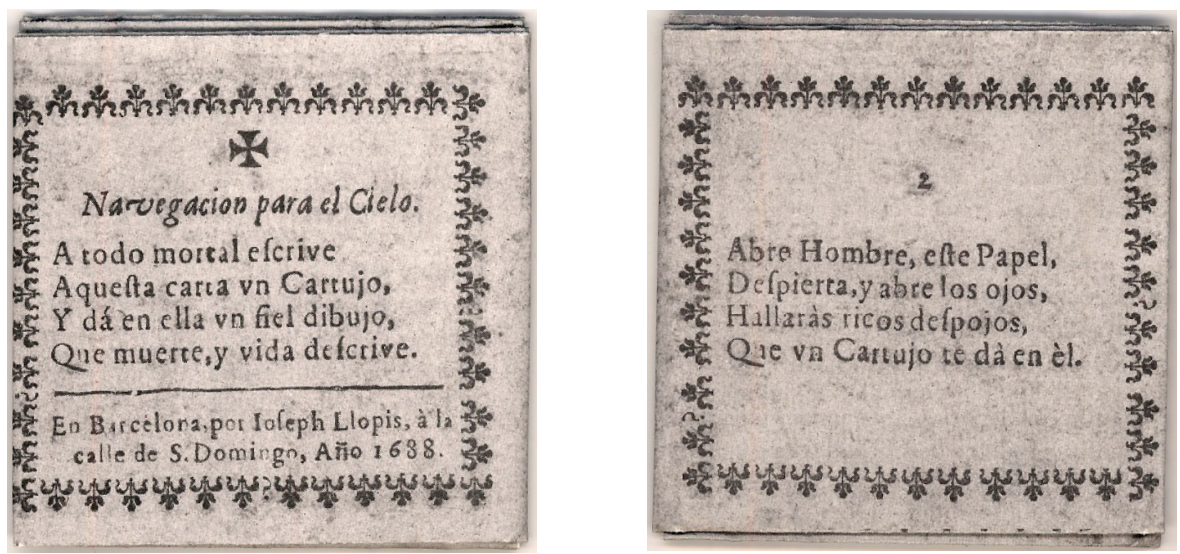

Figura 6. Navegación para el cielo, editio princeps. Tipograma 1.

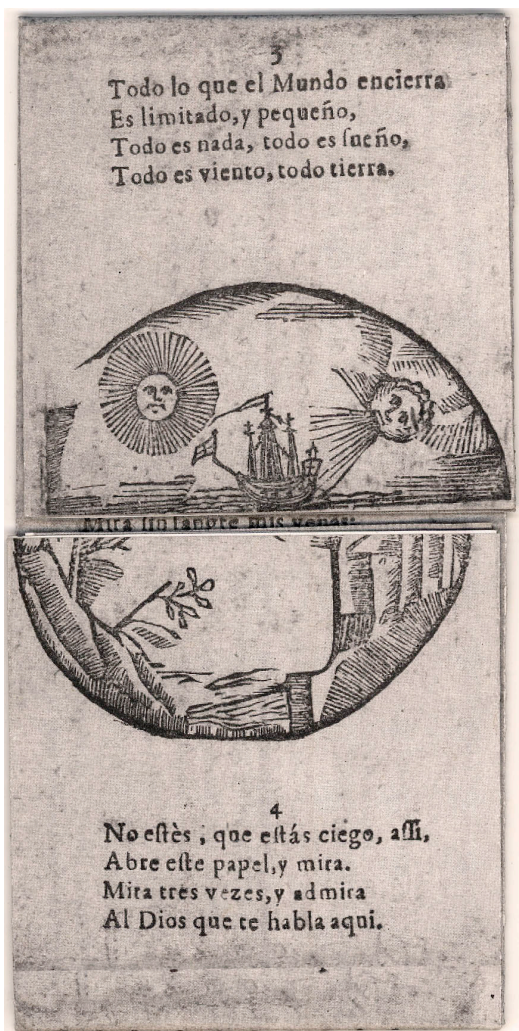

Figura 7. Navegación para el cielo. Tipograma 2.

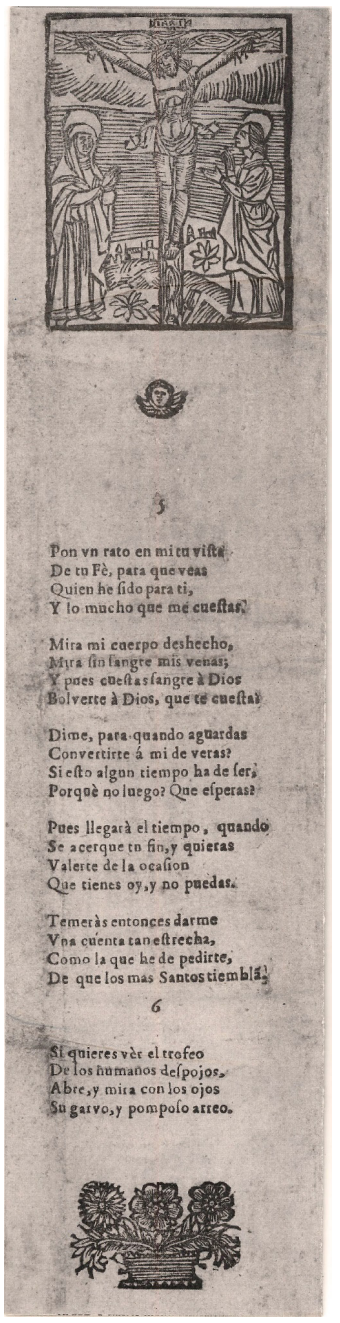

Figura 8. Navegación para el cielo. Tipograma 3. 


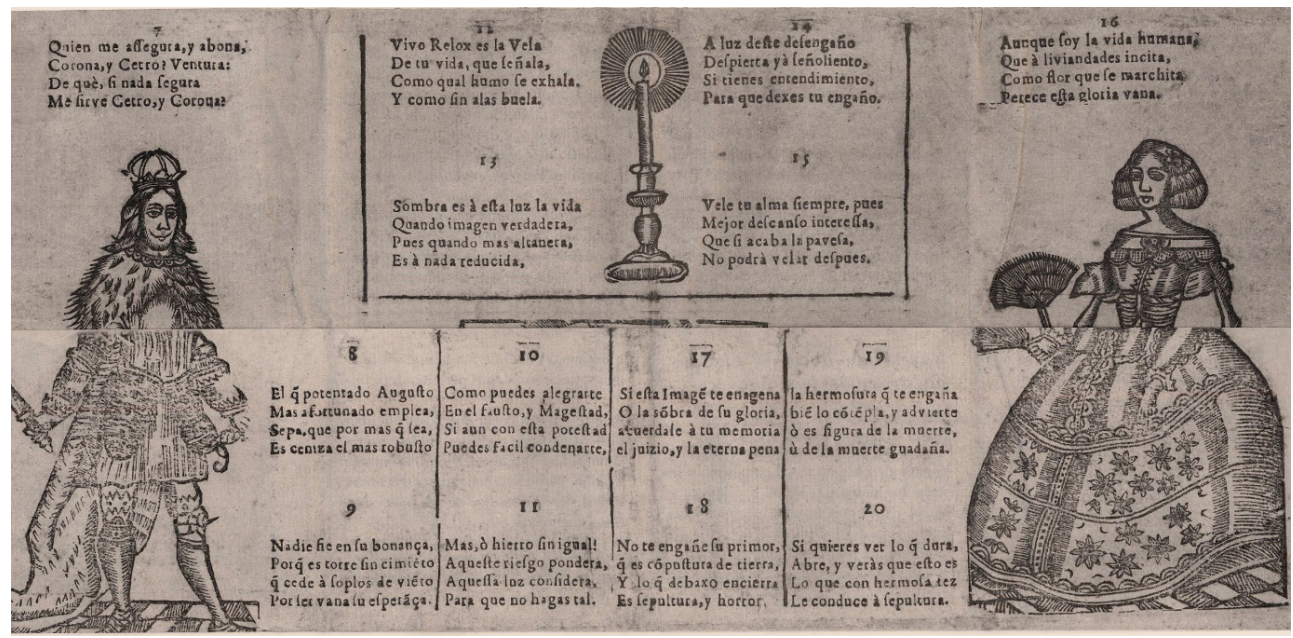

Figura 9. Navegación para el cielo. Tipograma 4.

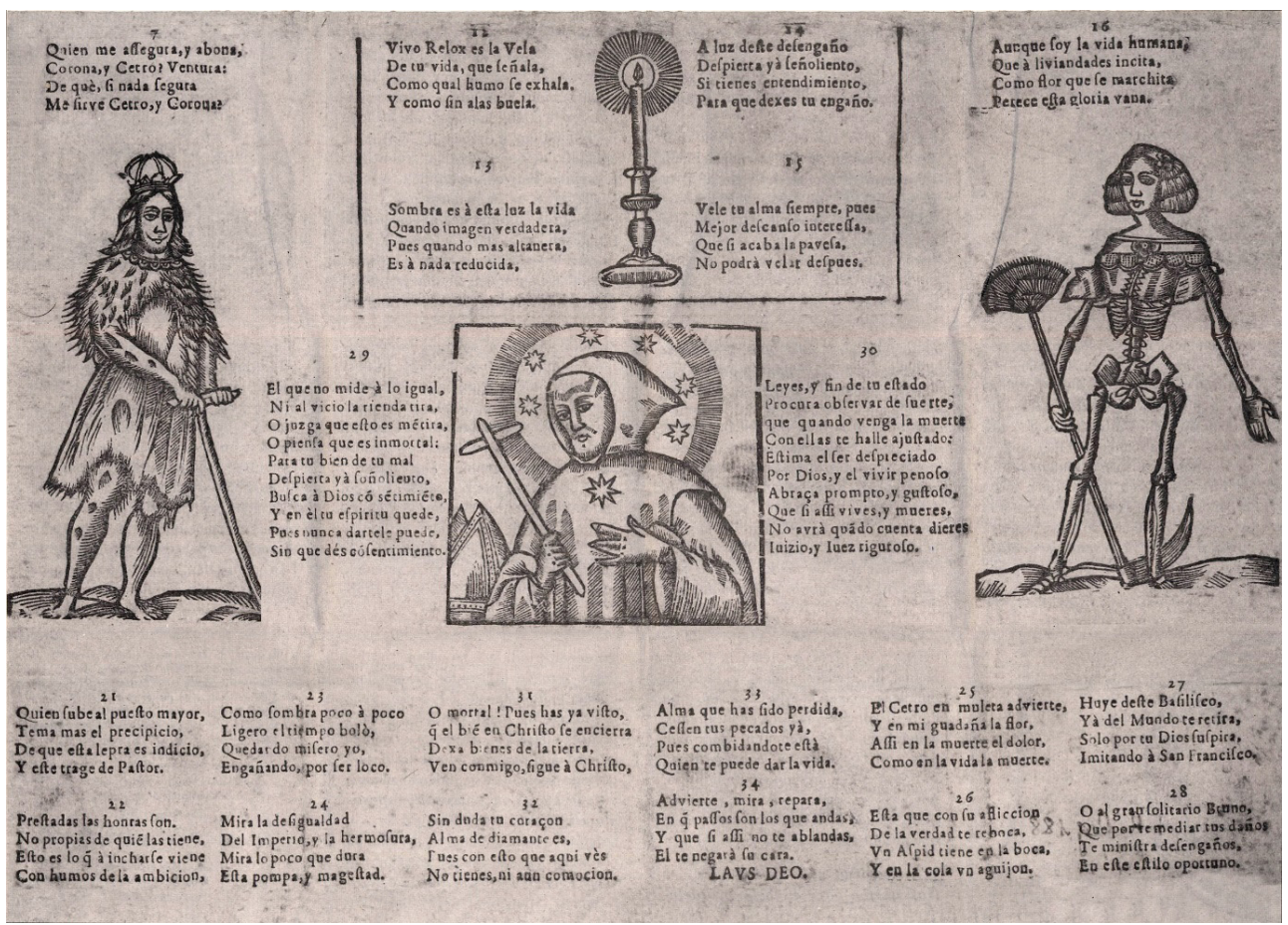

Figura 10. Navegación para el cielo. Tipograma 5.

La cuidada composición de esta Carta hace de ella un híbrido iconográfico y textual, "como si la imagen atrajera a las palabras que la explican"66. Al final de los cuatro primeros tipogramas, varias estrofas instan al lector a seguir descubriendo el 
poema, como diría Luis de Góngora, "velo a velo" este papel"), la $4^{\mathrm{a}}$ (v. 2: "Abre este papel y mira"), la $6^{\mathrm{a}}$ (v. 3: "Abre y mira con los ojos"), y la $20^{a}$ (v. 2: "Abre y verás que esto es"). El uso reiterado del imperativo renueva a cada paso la maravilla de un proceso de aprendizaje ordenado en varios instantes de revelación. El anuncio del último tipograma recurre a su vez al futuro ("verás"), tras el cual la redondilla 31 hace el balance de la rapidez del proceso, solo 150 versos después de empezar a navegar, con el recurso al pasado (v. 1-2: "Oh mortal, pues que ya has visto / que el bien en Cristo se encierra..."). Tan eficaz aprendizaje se basa en una cuidada disposición del papel, como por ejemplo en los tipogramas cuarto y quinto. En ambos tipogramas, el centro es el campo del discurso cartujo, con la vela a cuya luz debe despertar el alma, y con la imagen de san Bruno y su discurso al lector. A izquierda y derecha de este tríptico de papel, tanto las redondillas como los grabados pertenecen al campo de los hombres vanos, rey y dama. En el último tipograma, la disposición del texto y, en algunas ediciones, la orla de filetes que lo rodean, construyen además una pirámide o un altar alrededor del rostro del santo ${ }^{68}$. Por otra parte, a cada paso de la lectura la orientación del texto tiene una gran importancia, siendo horizontal en los tipogramas primero, cuarto y quinto, y vertical en el segundo y el tercero. Estos dos pueden por tanto leerse seguidos, y el descubrimiento de la Crucifixión cobra por ello mayor fuerza de impacto. De alguna manera, en virtud de esa variación en la orientación de los tipogramas y de su organización formal, esta Carta es una doble apariencia: primero se descubre a Cristo detrás de los engaños del mundo, después los "humanos despojos" detrás de su "pomposo arreo" (n. 6, v. 2 y 4).

Reivindicándose como una epístola en verso y en imágenes, esta Carta... juega desde el paratexto con la idea de desvelar un saber oculto, como si de una valiosa carta lacrada se tratase, dirigida al lector que va a abrirla una y mil veces ${ }^{69}$. El título, Navegación para el cielo, se sitúa en competencia con la literatura científica relativa al arte de la navegación ${ }^{70}$. La primera ilustración es de hecho un globo terráqueo, en el que un navío es empujado hacia el sol por una figura de Eolo. Esta imagen geográfica puede ser interpretada como una figura del alma navegando hacia el cielo, pero también funciona como un frontispicio detrás de la portada del tipograma primero, plegado como un libro. De esta manera, el grabado del globo alude a los frontispicios de infinidad de atlas, como la Cosmographia de Münster de 1550 o varias obras de Mercator u Ortelius ${ }^{71}$. Asimismo, el propio plegado de la plana remite al modelo formal de los mapas. El cambio en la orientación del texto y el orden numerado de la lectura, que sin ser laberíntico tampoco es evidente, representan la derrota del navío del alma hacia el cielo, asemejando esta Carta a una "carta de marear"72. Tanto

67 "Nace el niño y, velo a velo...", Góngora, L.: Poesía [en línea], ed. A. Carreira, París, Obvil, 2016, https://obvil. sorbonne-universite.fr/corpus/gongora/gongora_obra-poetica [Consulta: 20 de junio de 2020], n. 409.

68 Especialmente en la edición sevillana, por Aragón y Compañía (1816).

69 Este parece ser el modelo de un documento similar, la carta de Pablo Minguet e Yrol "A los mortales avisa / con horrible desengaño / enseñando el mismo Infierno / del mundano gusto, el daño" ("Paulus Minguet fecit Matriti", s. a.), cuyo primer verso reza "Abre esta carta y verás", mostrando en sucesivos despliegues estampas de unos jugadores de cartas y de un sarao, tras los cuales aparecen demonios y penas infernales.

70 No es el primer texto que reescribe a lo divino este modelo, véase Segorbe, J.: Navegación para el cielo, En Valencia, por Felipe Mey, 1611.

71 Besse, J.M., Les grandeurs de la Terre. Aspects du savoir géographique à la Renaissance, Lyon, ENS Éditions, 2003, pp. 41-42, 128, 267.

72 Galindo, op. cit. (nota 59). 
la especulación sobre este orden numerado, como la práctica de la lectura manual, transmiten su carga de enseñanzas. En la recurrencia de las estrofas, solo el número 5, bajo el grabado de la Crucifixión, contiene más de una estrofa. Las cinco cuartetas del número 5 en un papel con cinco pliegues insisten en la cifra de las heridas de Cristo, patente para cualquiera que observe la Carta con la curiosidad matemática que se espera de un piloto ${ }^{73}$. Por otra parte, el cambio de orientación del texto, entre el tipograma primero con el paratexto y el tipograma segundo, con las redondillas que acompañan el grabado del mundo, obliga al lector a enderezar el papel nada más abrirlo, haciendo girar el globo noventa grados a la derecha, como si jugara con una brújula de papel o probara su pericia en la geometría angular ${ }^{74}$. Estas alusiones a formatos editoriales, universos metafóricos y conocimientos técnicos relativos al saber geográfico son reinterpretadas a lo divino en esta Carta, semejante por ello a algunas de las más ambiciosas empresas editoriales católicas de la segunda mitad del XVII ${ }^{75}$. En este sentido pueden interpretarse algunas fórmulas del texto: la presentación del conjunto como un "fiel dibujo" $(1$, v. 3$)$ y una "imagen verdadera" $(13$, v. 2$)$, la insistencia en que el lector despierte (2, v. 2), se desengañe y, sobre todo mire y "mir[e] mil veces" (4, v. 3) la verdad y la fidelidad del mapa. "Advierte, mira y repara / qué pasos son los que andas", así se despide el poema de su lector en la última estrofa del papel (34, v. 1-2). Por los ojos y hasta el "entendimiento" $(14$, v. 3$)$ y la "memoria" $(17$, v. 3), la lección del Cartujo transmite al lector un saber religioso presentado como ciencia del desengaño y geografía espiritual, capaz de guiar, una vez acabada la lectura, los pasos del devoto por el mundo.

Pero la voz del cartujo no promete enseñanza sin placer y golosina ${ }^{76}$ : "Mira mil veces y admira / al Dios que te habla aquí" (4, v. 3-4). La admirable maravilla de una revelación acompaña la formalización del saber geográfico y religioso. Como afirmó Botrel, el papel propone "una suerte de autopredicación que recurre, para un uso privado, a formas, temas y métodos 'públicos"' "77. En manos del lector, el despliegue espectacular del papel reproduce de hecho varios aspectos de la "apariencia" teatral y de sus usos litúrgicos, con imágenes, con música y hasta con un posible recurso a la luz. En lo referente a las imágenes, manipular esta "papiroflexia espiritual" ${ }^{78}$ supone verlas crecer en un papel que se despliega paso a paso. Este no es solo el resultado de la diferencia de tamaño existente, por ejemplo, entre el mundo del segundo tipograma y las figuras del rey y la dama de la plana final, casi un tercio mayores. También es un cambio de perspectiva o de escala: después del primer tipograma carente de

73 Me he inspirado, para la distinción entre la navegación práctica y especulativa y para la complejidad de la comprensión matemática y geométrica del arte de navegar, de Nájera, A.: Navegacion especulativa y pratica, reformadas sus reglas y tablas por las observaciones de Ticho Brahe, con emienda de algunos yerros essenciales. Todo prouado con nueuas supposiciones mathematicas, y demonstraciones geométricas..., en Lisboa, por Pedro Craesbeeck, 1628.

74 Del mismo modo que el espectador ideal de Michael Baxandall era capaz de medir los volúmenes de las representaciones pictóricas: Baxandall, M.: Painting and Experience in Fifteenth century Italy, Oxford, Oxford University Press, 1988, p. 86 ss.

75 Como el Atlas Marianus, del que trata Christin, O.: "Qui porte le Monde ? Christophe, Atlas, Hercule et Marie (1570-1650)", Revue de l'histoire des religions, 232-2 (2015), pp. 183-210.

76 Bouza, F.: Papeles y opinión: políticas de publicación en el Siglo de Oro, Madrid, Consejo Superior de Investigaciones Científicas, 2008, pp. 45-65.

77 Botrel, op. cit. (nota 59), p. 73 (“une sorte d'autoprédication qui reprend, pour des usages privés, des formes et des thèmes ou des méthodes 'publiques"').

78 Ortiz García y Costa, op. cit. (nota 59). 
imagen, la primera ilustración es una mezcla de corografía y geografía ${ }^{79}$; a continuación, la Crucifixión es una escena de historia o retrato en grupo; las figuras del rey y la dama son retratos en pie; la vela un detalle de naturaleza muerta y san Bruno un retrato en busto. Esta sucesión de formatos implica un acercamiento progresivo a la representación, desde el aniconismo inicial y el lejanísimo plano geográfico del globo terráqueo hasta el primerísimo primer plano del rostro del cartujo al que el lector debe imitar (27-28). El Mundo, enemigo del hombre al igual que el Demonio y la Carne, se encuentra literalmente más lejos del lector que la vela del desengaño y el rostro del santo. Además, es de notar que su formato, su centralidad y el cuadrado que lo enmarca hacen del retrato de san Bruno una réplica de la forma y las dimensiones del papel, cuando se encuentra cerrado como un librillo. De esta manera, el retrato del santo se convierte en la imagen de memoria del conjunto ${ }^{80}$. Este travelling tan cinematográfico hacia el rostro de Bruno se corresponde por otra parte con importantes modelos litúrgicos del desvelamiento. Baste citar el retablo tramoya del Real Colegio Seminario del Corpus Christi de Valencia, que descubre, detrás de la Cena de Ribalta y sus figuras de tamaño natural, un Cristo en cruz tallado de tamaño sobrenatural $^{81}$; el majestuoso retrato de Isabel de Borbón tras el frontispicio cortinado del libro de la Pompa funeral seguiría este mismo patrón.

En algunas ediciones de la Navegación para el cielo, el tamaño de los tipos también varía, aumentando sensiblemente en las redondillas 12 a 15 (alrededor de la vela) y en las décimas 29 y 30 pronunciadas por el santo cartujo ${ }^{82}$, como si el poema también se dejara arrastrar en el acercamiento al lector que construye el papel ${ }^{83}$. Este aumento del tamaño del texto subraya la importancia del discurso directo de san Bruno pero también su diferencia, en términos estróficos, respecto al conjunto de las redondillas que lo rodean. Y es que la polimetría de esta Carta es un ingrediente esencial de su comprensión, pues compone una sencilla y eficaz partitura para las "apariencias" de la Navegación para el cielo. En los usos litúrgicos de esta puesta en escena, las reliquias e imágenes se descubrían con música, como cuando se abrían las cortinas del Cristo del Corpus Christi valenciano y el Miserere que acompañaba la ceremonia se modulaba "en tono algo más bajo y con pausa conocida" 84 . En las apariencias genuinamente teatrales, es relativamente frecuente que un cambio métrico también coincida con el momento de la apertura de la cortina, sumando el cambio

79 Apianus, P.: Cosmographia, sive Descriptio universi orbis, Antuerpiae, ex officina Arnoldi Coninx, 1584, p. 3 , http://bdh-rd.bne.es/viewer.vm?id=0000000501\&page $=13$

80 Esa identidad formal entre el pliego cerrado y la imagen descubierta hace del conjunto una suerte de medallón de san Bruno. Botrel, op. cit. (nota 59), p. 73, n. 9, cita de hecho un pliegue que se presenta, por su doblez, como un "medallón" para llevar (BNE, INVENT/17724).

81 Doménech, F. B.: "El origen de la Cena del Real Colegio de Corpus Christi de Valencia en torno a Carducho y Ribalta", Boletín del Seminario de Estudios de Arte y Arqueología, 45 (1979), pp. 417-426.

82 Observamos tipos mayores que los de las demás redondillas del último tipograma del impreso en la edición de Sevilla, por Aragón y Compañía (1816) y, únicamente en las redondillas 12 a 15, en la de Barcelona, por Juan Centené y Juan Serra, ca. 1796.

83 Hasta tal que punto que ponen en jaque el orden de la lectura de la última plana, cosa que parece haber sido prevista por los autores de esta Carta.... En efecto, las dos redondillas situadas abajo a la izquierda de la plana (27-28), que corresponderían normalmente al final del poema, remiten a los "desengaños" de san Bruno, obligando al lector a volver a la estrofa 29. De esta manera el orden de lectura del último tipograma siempre le da la última palabra al cartujo, independientemente de si el lector sigue la numeración de las estrofas o la disposición del texto.

84 Ribera, J.: Constituciones de la Capilla del Colegio y Seminario de Corpus Christi, En Valencia, en casa de Pedro Patricio Mey, 1605, p. 33. 
de ritmo y de tonalidad a la irrupción de una visión espectacular en escena ${ }^{85}$. En este papel ocurre lo mismo, con dos cambios métricos situados precisamente en el tipograma tercero y en el quinto. Así, cuando se abre el mundo y aparece la Crucifixión, Cristo le habla al lector en cuartetas asonantadas y no en redondillas (6, v. 1: "Pon un rato en mí la vista"). Con esta forma común en los villancicos se reduce el ritmo de recurrencia de la rima, presente solo en los versos pares, aquí en asonancia continuada, de manera que el discurso se vuelve más pausado y grave, pudiendo eventualmente ser cantado ${ }^{86}$. Lo mismo ocurre cuando se abre la plana completa, quitándole los ricos ropajes a las figuras y descubriendo a san Bruno, con las estrofas 29 a 34 de su discurso. Las dos primeras estrofas que rodean al santo son décimas (29-30), estrofas quizá de mayor dignidad, y en todo caso de mayor extensión y aliento que las redondillas. En la Navegación para el cielo, la polimetría restituye con sus variaciones rímicas y rítmicas la banda sonora de los desvelamientos: al hilo de las lecturas y de su memorización, no sería extraño que todo el poema fuera cantado, como en otros artefactos editoriales coetáneos, dedicándose la vista únicamente a la contemplación de las estampas ${ }^{87}$.

En cuanto a la luz, esta aparece en la vela y en el busto de san Bruno con sus siete estrellas y su aureola, que pretenden deslumbrar al lector. Por un ingenioso efecto de la composición, estos dos grabados se descubren en el papel ya desplegado. En el tipograma cuarto, la vela contrasta de hecho con los cuerpos del rey y la dama, todavía cubiertos por el pliegue del papel que representa sus ropajes. En consecuencia, la transparencia del papel es mayor en aquellos lugares en los que se encuentran la vela y el santo ${ }^{88}$. La materia misma del impreso se ilumina de esta manera, como una reinterpretación en papel de las abundantes luces que acompañaban los desvelamientos litúrgicos.

La Navegación para el cielo se caracteriza por tanto por una enorme interactividad, que activa los distintos niveles de sentido del conjunto, en base a una lógica contradictoria que enseña las seducciones mundanas para rebatirlas acto seguido ("si esta imagen te enajena", "abre y verás...", 17, v. 1; 20, v. 2). Cerrado, el pliego podría ser algo así como una carta lacrada, un amuleto textual, o un medallón de papel que se abre descubriendo la estampa de san Bruno. Como la carta, el amuleto o la joya, este curioso impreso apela sin duda alguna a la intimidad con el lector y a su fe en las imágenes mostradas y en su eficacia apotropaica ${ }^{89}$. Sin embargo, son los cinco despliegues, como cinco desvelamientos, los que construyen la lectura de la Carta en toda su complejidad. En la apertura del papel se descubre el saber religioso que atesora, contra la vanidad del mundo y los engaños de la carne. En la misma apertura se

Ruiz Soto, op. cit. (nota 8).

86 Sobre esta estrofa y el género del villancico: Baehr, R.: Manual de versificación española, trad. Wagner, K. y López Estrada, F., Madrid, Gredos, 1973, pp. 245-247.

87 Rueda Ramírez, P.: "Efímeros de fe: estrategias de distribución de impresos y estampas devotas en Cataluña (siglos XVII-XVIII)", La Bibliofilia: rivista di storia del libro e di bibliografia. vol. 121 (2019), pp. 327-349, especialmente pp. 343-346.

88 Detrás de la vela y del santo se encuentran también los dos puntos más frágiles del papel, correspondientes a las esquinas plegadas del librillo completamente cerrado: son los puntos en los que la superposición de los pliegues crea mayor tensión, y también los más expuestos a roces y desgarros. Por tanto, ahí es donde el papel empezaría a romperse, dejando pasar la luz con mayor facilidad que cualquier otro pliegue: así ocurre en el ejemplar de la BC, II (i).2 B R.E. 28165.

89 Koos, M., "Concealing and Revealing Pictures 'In Small Volumes': Portrait Miniatures and their Envelopes", Espacio, tiempo y forma, 6 (2018), dossier Bodart, D. (dir.): Imágenes portadas, pp. 33-54. 
activan las semejanzas del papel con los formatos y saberes de la ciencia geográfica. En definitiva, la visibilidad del conjunto ha de ser entendida como la escenografía de un proceso en el que varios descubrimientos, equivalentes a varios instantes de aprendizaje, le enseñan al devoto el camino que deben seguir sus pasos.

Estos instantes son los de una continua sorpresa, un juego, como diría Víctor Infantes, pero didáctico e interpretativo, capaz de provocar lo que Huizinga llamó un "corto-circuito" racional": en definitiva un juego serio del que depende la conversión del devoto y su salvación. La eficacia del desvelamiento aspira a igualar la de alguno de sus modelos, como el célebre Cristo de Burgos, que sanó a una mujer muda y sorda con solo descubrirse ante ella:

Y después de haber oído una misa muy devotamente en su bendita capilla, quitaron los velos que están delante de aquella preciosa imagen, y puestos los ojos en ella, estando orando esta enferma con oración de corazón, luego de improviso sanó y le fue concedida la habla y el oír perfectamente, y dio gracias a Dios con los que presente estaban por tan gran maravilla ${ }^{91}$.

Tal maravilla de la "apariencia" milagrosa, capaz de curar en el momento en que se abren sus velos, se repite como una aspiración en la Carta del Cartujo: "No estés, que estás ciego así" $(4$, v. 1). Las "apariencias" de este papel pretenden sanar al devoto "luego de improviso" mediante el desengaño. El "mecanismo lúdico y didáctico" de la Navegación para el cielo conecta así con otros artefactos característicos de la "enseñanza de las postrimerías" ciadas desde Barcelona por el clérigo Magí Cases a finales del siglo XVII apelan al mismo tipo de "libro tridimensional" con estampas como uno de sus recursos didácticos más novedosos. Es el caso de los Desenganys del Apocalypsis (ca. 1674, 1694), cuyas imágenes forman un "teatrillo" que plasma la apariencia del infierno y la gloria, detrás de la muerte y del juicio. Esta tipología de teatros tipográficos se asemeja todavía a otras imágenes desveladas del desengaño y la vanidad, como el extraordinario Espejo de clarisas de las Descalzas Reales (Patrimonio Nacional, inv. 00619116), que descubre el retrato de una calavera con tocado de clarisa, detrás de una tapadera corrediza que anima a la espectadora a contemplar "lo que has de ser [...] en la luna de este espejo" $"$. Un cuadro tan célebre como la Alegoría de la Vanidad de Valdés Leal (Hartford, Wadsworth Atheneum) hace lo propio. En él, un ángel desvela una pintura del Juicio Final mientras mira fijamente al espectador. Al levantar un velo encarnado, metáfora común de ese "mortal velo" que es la vida o la carne que encubre el alma ${ }^{94}$, el ángel de Valdés Leal no hace sino remitir el instante de la revelación al instante de la muerte y del Juicio. La décima n. 30 de la Carta del

Huizinga, J.: Homo ludens, Paris, Gallimard, 2017, p. 238.

91 Libro de los milagros del sancto crucifixo, de San Augustin de la ciudad de Burgos, en Burgos, por Pedro de Huydobro ..., 1622, fol. 87r.

92 Rueda Ramírez, op. cit. (nota 87), p. 334. A continuación cito las pp. 340 y 342.

93 La otra Corte. Mujeres de la Casa de Austria en los Monasterios Reales de las Descalzas y la Encarnación, Madrid, Patrimonio Nacional, 2019, p. 29. La leyenda reza: "Lo que en mi vienes a ver / te pido que consideres / y enmendaras lo que eres / mirando lo que has de ser: / la hermosura y el Poder / el Donayre, y el Despejo, / con otras Gracias que dejo / tus Esperanzas burlaron, / por que todas se quedaron / a la Luna de este Espejo".

94 En la doble tradición exegética y lírica: véase Ruiz Soto, op. cit. (nota 25), pp. 183-261 y Ponce Cárdenas, J.: La imitación áurea (Cervantes, Quevedo, Góngora), Paris, Éditions Hispaniques, 2016, pp. 166-168. 
cartujo alude al mismo instante fatídico, mostrando así que en sus "apariencias" está en juego la habilidad del lector para aprender del instante y aprovechar la ocasión de salvarse, quitándose el velo cegador de la carne. En términos de Juan Pimentel, analizando la Vanitas de Antonio Pereda (1670, Florencia, Gallerie degli Uffizi), con otro Juicio final desvelado:

El ángel de Pereda nos mira mientras nos invita -también-a "volver a mirar". Nos propone una mirada filosófica - profunda- sobre la transitoriedad de la vida y la futilidad de las cosas terrenas, agitando el tópico clásico y cristiano del comtemptus mundi (el menosprecio del mundo). De alguna manera, el objeto del lienzo no es procurarle un goce estético al espectador, sino aleccionarle, hacerle más sabio. En este sentido, el óleo es un artefacto científico ${ }^{95}$.

El desvelamiento es otro artefacto científico que, como las pinturas de vanitas, tan atentas a la anatomía, se sitúa en el cruce de la tradición litúrgica y de la modernidad editorial y científica. La brevedad de la revelación de la Carta del cartujo no debe llevar a engaño: la aparente simplicidad del mensaje oculta materia suficiente para profundas meditaciones y glosas, como las que Cases desarrolla en verdaderos libros que acompañan la edición suelta, como menudencia de imprenta, de las estampas de sus Desenganys ${ }^{96}$. El instante en el que se cifra todo el saber de una vida devota, in articulo mortis, será la última de las revelaciones en un mundo de "apariencias".

\section{Conclusión: El conocimiento de la "apariencia" y las transformaciones de la imagen}

Para Gracián la cortina del desengaño en el trono de Vegecia se oponía a la cortina del engaño en el teatro. Sin embargo, las apariencias del teatro, comparables a desvelamientos rituales connotados de forma positiva, componen un patrón espectacular coherente. En sus implicaciones epistemológicas, este patrón puede verse asociado al descubrimiento de una verdad: tanto en el teatro, como por supuesto en el uso ritual de la cortina. La vera effigies de los santos en su canonización ${ }^{97}$, o el rostro del Rey Católico en la cortina de su capilla así lo manifiestan. El mundo del libro áureo se hace eco de las connotaciones espectaculares y epistemológicas del dispositivo de la apariencia. Entre infinidad de percepciones visuales, entre multitud de apariencias engañosas, la cortina de apariencias descubre la verdad.

Así, el uso de velos y cortinas en la ilustración de los frontispicios de multitud de impresos pone de manifiesto la existencia de una estrategia editorial para hacer publicidad del secreto. Algunos libros ilustrados entre los más célebres y más difundidos de la época, como las Vite de Vasari, las arquitecturas de Barbaro o Serlio, o anatomías como la de Bartholin gozaron de tal dispositivo editorial, en el que incluso

\footnotetext{
Pimentel, op. cit. (nota 37), p. 106.

Señaladamente la Idea de la alma arrepentida, véase Rueda Ramírez, op. cit. (nota 87), pp. 341-342.

Boiteux, M.: "Le rituel romain de canonisation et ses représentations à l'époque moderne", en Klaniczay, G. (ed.), Procès de canonisation au Moyen Âge: aspects juridiques et religieux, Rome, École française de Rome, 2004, p. 334.
} 
participaron directamente sus autores, como en el caso de Vasari. La lectura de estas obras se convertía así en un espectáculo maravilloso, interactivo y sorprendente, para regalarle al lector el privilegio de un conocimiento arcano. El cambio estudiado por Carlo Ginzburg a lo largo de los siglos XVI y XVII, que vio el paso de la prohibición de conocer lo superior (Altum sapere pericolosum) a la valoración positiva del conocimiento, encuentra su reflejo en el mercado del libro ${ }^{98}$. Sapere aude: hay que atreverse a saber, y para ello abrir las cortinas, sin todavía romperlas ni renunciar a su prestigio ${ }^{99}$.

La Navegación para el cielo literaliza todavía más la asimilación de la lectura a una "apariencia" o desvelamiento. Este papel reinterpreta algunas de las características que definen las "apariencias" del teatro o la liturgia de los siglos XVI y XVII, como son la importancia de la visión como vía del conocimiento, el acompañamiento de música y hasta de luz. Cada despliegue descubre un saber espiritual plasmado como un conocimiento geográfico a lo divino. Por su mezcla de imagen y texto, religión y geografía, maravilla y argumentación, este papel es una de esas "mediaciones espectaculares", características de los siglos XVII y XVIII, "que hacían de la curiosidad, de la maravilla y del entusiasmo regímenes de conocimiento" ${ }^{100}$ tan válidos y legítimos como los que hoy en día situamos en el ámbito científico. Al mostrar el esqueleto de la dama y la pobreza del rey debajo de sus trajes y sus galas, este papel nos permite acceder a "la mirada del ángel": la construcción de una imagen inaccesible al ojo humano, que progresivamente se independizará de la teología en beneficio de la microscopia, pero manteniendo una misma aspiración al ensanchamiento de las capacidades humanas ${ }^{101}$. Dentro de esa evolución hacia una cientificidad moderna, y en un tiempo en el que la ciencia se desarrolla en discursos del método como el de Descartes, el conocimiento también se plasma en instantes de revelación y en el recurso a una cultura visual que apela a los sentidos y la memoria tanto como al entendimiento: la conexión de estas tres facultades así lo permite ${ }^{102}$. El saber tiene sus epifanías, su emoción y su maravilla: la "apariencia" es una de sus escenografías posibles, puesta aquí al servicio de la didáctica de las postrimerías.

En definitiva, estos espectáculos y sus tramoyas de papel se asemejan a la teatralización del saber científico en espectáculos de magia natural ${ }^{103}$ tanto como a la liturgia religiosa o monárquica propia de la "apariencia". Por su polivalencia, este recurso espectacular visibiliza la compatibilidad entre el culto de las imágenes y la puesta en escena de su valor probatorio o epistemológico. El paso del tiempo de las imágenes de culto a la era del arte, que Hans Belting sitúa a partir de la Reforma ${ }^{104}$,

98 Ginzburg, C.: “Lo alto y lo bajo. El tema del conocimiento vedado en los siglos XVI y XVII”, ed. consultada Mythes, emblèmes, traces: morphologie et histoire, Lagrasse, Verdier, 2010, pp. 160-184.

99 Durante la Revolución Francesa, el deseo de romper el velo es una idea recurrente, como en la sesión parlamentaria del 25 de septiembre de 1793, en la que se oye la expresión "il faut déchirer le voile", apud Brunel, F. y Guilhaumou, J.: "Extrême, extrêmes: réflexions sur Marx, le côté gauche et les Montagnards" [en línea], en Biard, M. y otros, "Extrême?” Identités partisanes et stigmatisation des gauches en Europe (XVIII"-XXe siècle), $\S 27$.

100 Thébaud-Sorger, op. cit. (nota 28), p. 138.

101 Pimentel, op. cit. (nota 37), pp. 97-137.

102 Aunque los últimos avances de la óptica cartesiana empiezan a romperla en la primera mitad del siglo XVII. Véase Simon, G.: Archéologie de la vision. L'optique, le corps, la peinture, París, Seuil, 2003, pp. $231-241$.

103 Reula Baquero, P.: El camarín del desengaño. Juan de Espina, coleccionista y curioso del siglo XVII, Madrid, CEEH, 2019, pp. 307-411

104 Véase Belting, H.: Image et culte: une histoire de l'image avant l'époque de l'art, trad. F. Muller, Paris, les 
no agota por tanto la descripción de las transformaciones de la imagen en la edad moderna. El arte, la ciencia y la religión, lejos de ser contradictorios o de sucederse en tiempo como paradigmas enfrentados, son ámbitos interrelacionados del uso de las imágenes modernas ${ }^{105}$. La "apariencia" es por tanto una técnica capaz de construir el aura del misterio, tanto como un teatro de la evidencia y un marco habitual para pinturas consideradas cada vez más como obras de arte. Con tales usos, no es de extrañar que "correr la cortina" signifique "hacer demostración de algún caso maravilloso".

\section{Bibliografía}

"A los mortales avisa / con horrible desengaño / enseñando el mismo Infierno / del mundano gusto, el daño", Madrid, Paulus Minguet [Pablo Minguet e Yrol], s. a.

Apianus, P.: Cosmographia, sive Descriptio universi orbis, Antuerpiae, ex officina Arnoldi Coninx, 1584, p. 3, http://bdh-rd.bne.es/viewer.vm?id=0000000501\&page $=1$ [Consulta: 20 de junio de 2020].

Baehr, R.: Manual de versificación española, trad. Wagner, K. y López Estrada, F., Madrid, Gredos, 1973.

Baranda, N.: "Los nobles toman cartas en la educación de sus vástagos", en García de Enterría, M. C. y Cordón Mesa, A. (eds.): Actas del IV Congreso Internacional de la Asociación Internacional Siglo de Oro, Alcalá, Universidad de Alcalá de Henares, 1998, vol. 1, pp. 215-224.

Barbaro, D.: I dieci libri della' architettura di M. Vitruuio, In Venetia, Apresso Francesco de' Franceschi senese, 1584.

Bartholin, T.: Thomae Bartholini Casp. F. Anatomia ex Caspari Bartholini, parentis institutionibus, omniumque recentiorum et propriis observationibus Reformata cum iconibus novis accuratissimis, Lugduni Batavorum, Ex officina Francisci Hackii, 1651.

Bass, L. y Peraita, C., “'Cubriendo y velando en la primera hoja’: Antonio León Pinelo y los contextos culturales de Velos antiguos i modernos (1641)", en Martín, A.L. y Quintero, M.C. (eds.), Perspectives on Early Modern Women in Iberia and the Americas: Studies in Law, Society, Art and Literature in Honor of Anne J. Cruz, Nueva York, Escribana Books, 2015, pp. 615-631.

Baxandall, M.: Painting and Experience in Fifteenth century Italy, Oxford, Oxford University Press, 1988.

Belli, S.: Libro del misurar con la vista, Venecia, Giordano Ziletti, 1569. https://archive.org/ details/ARes10516/page/n5/mode/2up [Consulta: 20 de junio de 2020].

Belting, H.: Image et culte: une histoire de l'image avant l'époque de l'art, trad. F. Muller, Paris, les Éditions du Cerf, 2007.

Belting, La vraie image. Croire aux images?, trad. J. Torrent, Paris, Gallimard, 2007.

Benjamin, W.: Oeuvres, t. III, Paris, Gallimard, 2000.

Besse, J.M., Les grandeurs de la Terre. Aspects du savoir géographique à la Renaissance, Lyon, ENS Éditions, 2003.

Éditions du Cerf, 2007, y Belting, La vraie image. Croire aux images ?, trad. J. Torrent, Paris, Gallimard, 2007, pp. 209-251, y esp. p. 242.

105 Como lo defiende con contundencia Pereda, F.: Crimen e ilusión. El arte de la verdad en el Siglo de Oro, Madrid, Marcial Pons, 2017. 
Boiteux, M.: "Le rituel romain de canonisation et ses représentations à l'époque moderne", en Klaniczay, G. (ed.), Procès de canonisation au Moyen Âge: aspects juridiques et religieux, Rome, École française de Rome, 2004, pp. 327-354.

Bolzoni, Lina, La chambre de la mémoire, Ginebra, Droz, 2005.

Bord, L. J., Debiais, V. y Palazzo, E.: Le rideau, le voile et le dévoilement: du Proche-Orient ancien à l'Occident médiéval, Paris, Geuthner, 2019.

Botrel, J. F., "Sur les usages de l'imprimé. La Navegación para el cielo ou le jeu du chartreux", en Moner, M. y Clément, J.P., Hommage des hispanistas français à Henry Boneville, Tours, Societé des Hispanistes Français de 1'Enseignement Supérieur, 1966, pp. 59-74.

Bouza, F.: “Dásele licencia y privilegio”. Don Quijote y la aprobación de libros en el Siglo de Oro, Madrid, Akal, 2012.

- Hétérographies: formes de l'écrit au Siècle d'or espagnol, Madrid, Casa de Velázquez, 2010.

- Imagen y propaganda. Capitulos de historia cultural del reinado de Felipe II, Madrid, Akal, 1998.

- Papeles y opinión: políticas de publicación en el Siglo de Oro, Madrid, Consejo Superior de Investigaciones Científicas, 2008.

Brunel, F. y Guilhaumou, J.: "Extrême, extrêmes: réflexions sur Marx, le côté gauche et les Montagnards", en Biard, M. y otros, "Extrême?" Identités partisanes et stigmatisation des gauches en Europe (XVIII $-X X^{e}$ siècle), § 27, https://books.openedition.org/ pur/126921 [Consulta: 20 de junio de 2020].

Carducho, V.: Diálogos de la pintura, Madrid, Francisco Martínez, 1634.

Carvalho, J. A. F.: Pais e nobres. I. Cartas de instrução de jovens nobres (séculos XVI-XVII), II. A descendência portuguesa de um texto célebre: A Instrucción de Juan de Vega a seu filho Hernando de Vega (1548), Porto, Centro Inter-Universitário de História da Espiritualidade, 2009.

Christin, O.: "Qui porte le Monde ? Christophe, Atlas, Hercule et Marie (1570-1650)", Revue de l'histoire des religions, 232-2 (2015), pp. 183-210, https://doi.org/10.4000/rhr.8395 [Consulta: 20 de junio de 2020].

Covarrubias, S.: Tesoro de la lengua castellana o española, ed. I. Arellano y R. Zafra, Pamplona, Madrid y Fráncfort, Universidad de Navarra, Iberoamericana-Vervuert, 2006.

Doménech, F. B.: "El origen de la Cena del Real Colegio de Corpus Christi de Valencia en torno a Carducho y Ribalta", Boletín del Seminario de Estudios de Arte y Arqueología, 45 (1979), pp. 417-426.

Egido, A.: "Telones parlantes del Siglo de Oro", en Blecua, L. A., Arellano, I., y Serés, G. (eds.): El teatro del Siglo de Oro: edición e interpretación, Pamplona/Madrid, Universidad de Navarra/Iberoamericana, pp. 113-173.

Fernández-Santos Ortiz-Iribas, J.: "Ostensio regis: la 'Real Cortina' como espacio y manifestación del poder soberano de los Austrias españoles", Potestas: Religión, poder y monarquía, 4 (2011), pp. 167-210.

Ferrer Valls, T.: Nobleza y espectáculo teatral (1535-1622). Estudio y documentos, Valencia. Freedberg, D.: The Eye of the Lynx, Chicago, University of Chicago Press, 2002.

Galindo, E., "Esfuerzo y desapego en la navegación para el cielo, un pasatiempo religioso del siglo XVIII", Scripta Nova, Revista Electrónica de Geografía y Ciencias Sociales, 6-119 (2002), http://www.ub.es/geocrit/sn/sn119-20.htm [Consulta: 20 de junio de 2020].

Gállego, J.: Visión y símbolos en la pintura española del Siglo de Oro, Madrid, Aguilar, 1972. Ginés de Sepúlveda, J.: El Diálogo llamado Demócrates, Sevilla, Juan Cromberger, 1541. 
Ginzburg, C.: " Lo alto y lo bajo. El tema del conocimiento vedado en los siglos XVI y XVII", ed. consultada Mythes, emblèmes, traces: morphologie et histoire, Lagrasse, Verdier, 2010, pp. 160-184.

Glass, J.: The Royal Chapel of the Alcázar: Princely Spectacle in the Spanish Habsburg Court, Baltimore, John Hopkins University, 2004.

Góngora, L.: Poesía [en línea], ed. A. Carreira, París, Obvil, 2016, https://obvil.sorbonne-universite.fr/corpus/gongora/gongora_obra-poetica [Consulta: 20 de junio de 2020].

Góngora, L.: Romances, ed. A. Carreira, Barcelona, Quaderns Crema, 1998, vol. IV.

González de Salas, J. A.: Nueva idea de la tragedia antigua o Ilustración última al libro singular de Poética de Aristóteles Stagirita, Madrid, Francisco Martínez, 1633.

Gracián, B.: El Criticón, ed. S. Alonso, Madrid, Cátedra, 1980.

Hadot, P.: Le voile d'Isis, Paris, Gallimard, 2004.

Helmstutler Di Dio, K.: "The chief and perhaps only antiquarian in Spain. Pompeo Leoni and his collection in Madrid", Journal of the History of Collections, 18-2 (2006), pp. 137-167, https://doi.org/10.1093/jhc/fh1026 [Consulta: 20 de junio de 2020].

Hernández, F.: Rerum medicarum novae Hispaniae thesaurus, seu Plantarum, animalium, mineralium mexicanorum historia, ex Francisci Hernandez,... relationibus in ipsa mexicana urbe conscriptis a Nardo Antonio Reccho,... collecta ac in ordinem digesta a Joanne Terrentio,... notis illustrata, Romae, ex. typ. V. Mascardi, 1649, https://www.wdl.org/es/ item/19340/view/1/5/ [Consulta: 20 de junio de 2020].

Huizinga, J.: Homo ludens, Paris, Gallimard, 2017.

Infantes, V.: “Ludo ergo sum. La literatura gráfica del juego áureo", en Bègue, A. y Herrán Alonso, E. (dirs.), Pictavia Aurea. Actas del IX Congreso de la Asociación Internacional "Siglo de Oro", Toulouse, Presses Universitaires du Midi, 2014a, pp. 35-55.

- Ludo ergo sum. La literatura gráfica del juego áureo, Madrid, Turpin Editores, 2014b.

- Lyra mixta. Silva ejemplar de artificios gráfico-literarios, Madrid, Turpin Editores, 2015.

Karr Schmidt, S.: Interactive and Sculptural Printmaking in the Renaissance, Leiden, Brill, 2018.

Kircher, A.: Athanasii Kircheri e Soc. Iesu China monumentis qua sacris qua profanis, nec non variis naturae \& artis spectaculis, aliarumque rerum memorabilium argumentis illustrata, Amstelodami, apud Joannem Janssonium à Waesberge \& Elizeum Weyerstraet, 1667. Véase http://bdh-rd.bne.es/viewer.vm?id=0000223429\&page=1 [Consulta: 20 de junio de 2020].

Koos, M., "Concealing and Revealing Pictures 'In Small Volumes': Portrait Miniatures and their Envelopes”, Espacio, tiempo y forma, 6 (2018), dossier Bodart, D. (dir.): Imágenes portadas, pp. 33-54, https://doi.org/10.5944/etfvii.6.2018.22873 [Consulta: 20 de junio de 2020].

Krischel, R.: "Cloths in and on paintings: from curtain to shutter and back again", en Costaras, N, y Young, C. (eds.), Setting the scene: European painted cloths from the fourteenth to the twenty-first century, Londres, Archetype Publications, 2013, pp. 1-10.

La otra Corte. Mujeres de la Casa de Austria en los Monasterios Reales de las Descalzas y la Encarnación, Madrid, Patrimonio Nacional, 2019.

Lavocat, F.: La Syrinx au bûcher: Pan et les satyres à la Renaissance et à l'âge baroque, Paris, Droz, 2005.

León Pinelo, A., Velos antiguos y modernos en los rostros de las mujeres: sus convenencias y daños: ilustración de la Real Premática de las tapadas..., En Madrid, por Iuan Sanchez, 1641.

Libro de los milagros del sancto crucifixo de San Augustin de la ciudad de Burgos, en Burgos, por Pedro de Huydobro, 1622. 
Mandresi, R.: "Le regard scientifique : cultures visuelles des sciences", en Van Damme, S. (dir.), Histoire des sciences et des savoirs. De la Renaissance aux Lumières, Paris, Seuil, 2015, pp. 230-253.

Maravall, J.A.: La cultura del Barroco. Análisis de una estructura histórica, Barcelona, Ariel, 1975.

Martínez, J.: Discursos practicables del nobilísimo arte de la pintura, ed. M. E. Manrique Ara, Zaragoza, Huesca y Teruel, Prensas Universitarias de Zaragoza, Instituto de Estudios Altoaragoneses e Instituto de Estudios Turolenses, 2008.

Montaigne, M. E.: Journal de voyage, ed. F. Rigolot, Paris, PUF, 2015, recurso electrónico.

Morales, A.: Viage de Ambrosio de Morales por orden del rey D. Phelipe II, a los reynos de Leon, y Galicia, y Principado de Asturias, para reconocer las reliquias de santos, sepulcros reales, y libros manuscritos de las cathedrales y monasterios, En Madrid, por Antonio Marin, 1765.

Nájera, A.: Navegacion especulativa y pratica, reformadas sus reglas y tablas por las observaciones de Ticho Brahe, con emienda de algunos yerros essenciales. Todo prouado con nueuas supposiciones mathematicas, y demonstraciones geométricas..., en Lisboa, por Pedro Craesbeeck, 1628.

Navegación para el cielo, Barcelona, por Juan Centené y Juan Serra, ca. 1796, BC, II (i).2 B R.E. 28165.

Navegación para el cielo, en Madrid, por J. M. Marés, 1848, BNE, U/11169(108).

Navegación para el cielo, en Manresa, por Ignacio Abadal, ca. 1800, BC, II (i).2 BC 1.

Navegación para el cielo, en Sevilla, por Aragón y Compañía, en 1816, BNE, R/35383(12).

Navegación para el cielo, S.1., s.n., s.a. [en Córdoba por Rafael Rodríguez (s. a.)], BNF, YG1933 e YG-1934.

Ortiz García, J.A. y Costa, N., "Papiroflexia espiritual”, Mesa revuelta: el diario de Studiolum [en línea], 5 de enero de 2011, http://mesa-revuelta.blogspot.com/2011/01/papiroflexia-espiritual.html [Consulta: 20 de junio de 2020].

Osuna, I. e Infantes, V.: "Paredes de versos dibujadas. Fábrica y materia del cartel poético barroco (1650-1700)", Bulletin hispanique, 113-1 (2011), https://doi.org/10.4000/bulletinhispanique.1336 [Consulta: 20 de junio de 2020].

Pereda, F.: Crimen e ilusión. El arte de la verdad en el Siglo de Oro, Madrid, Marcial Pons, 2017.

Pimentel, J.: Fantasmas de la ciencia española, Madrid, Marcial Pons, 2020.

Pompa Funeral, Honras y Exequias en la muerte de la muy alta y Católica Señora Doña Isabel de Borbon, Reyna de las Españas y del Nuevo Mundo que se celebraron en el... Convento de S. Geronimo de Madrid, [s.1.] Madrid, [s.n.] Diego Díaz de la Carrera, 1645.

Ponce Cárdenas, J.: La imitación áurea (Cervantes, Quevedo, Góngora), Paris, Éditions Hispaniques, 2016.

Reula Baquero, P.: El camarín del desengaño. Juan de Espina, coleccionista y curioso del siglo XVII, Madrid, CEEH, 2019.

Rey de Artieda, A., Virués, C. y Turia, R., Teatro clásico en Valencia I, ed. T. Ferrer, Madrid, Fundación José Antonio de Castro, 1997.

Ribera, J.: Constituciones de la Capilla del Colegio y Seminario de Corpus Christi, En Valencia, en casa de Pedro Patricio Mey, 1605.

Riera, E. y Eduardo, S.: "Si con toda precision / Me pliegas, desaparezco / Y en vez de ramo te ofrezco / Lo que está en el medallón”, S.1., s.n., 1875, BNE, INVENT/17724.

Rodríguez de la Flor, F.: Pasiones frías. Secreto y disimulación en el Barroco hispano, Madrid, Marcial Pons, 2005. 
Ruano de la Haza, J.M., y Allen, J.J., Los teatros comerciales del siglo XVII y la escenificación de la comedia, Madrid, Castalia, 1994.

Rueda Ramírez, P.: "Efímeros de fe: estrategias de distribución de impresos y estampas devotas en Cataluña (siglos XVII-XVIII)", La Bibliofilia: rivista di storia del libro e di bibliografia. vol. 121 (2019), pp. 327-349.

Ruiz Soto, H.: “¿Monstruos de apariencias llenos? Las escenas de descubrimiento y la cortina de apariencias en los manuscritos teatrales de Gondomar y de Palacio", Criticón, 140 (2020), pp. 27-51.

- Apariencia ou l'instant du dévoilement. Théâtre et rituels dans l'Espagne du Siècle d'Or, tesis de doctorado, Sorbonne Université, 2019.

Ruscelli, G.: De'secreti del reverendo donno Alessio piemontese, Venecia, appresso Domenico Farri, 1570.

Sagredo, D.: Medidas d[e]l romano: agora nueuamente impressas y añadidas de muchas pieças y figuras muy necessarias a los officiales que quieren seguir las formaciones de las basas, colunnas, capiteles y otras pieças de los edificios antiguos, Lisbona, imprimido por Luis Rodriguez..., 1541.

Santa María, F.: Reforma de los Descalzos de Nuestra Señora del Carmen de la primitiva Observancia hecha por Santa Teresa de Jesús, En Madrid, por Diego Diaz de la Carrera, 1644. Véase https://bibliotecadigital.jcyl.es/es/consulta/registro.cmd?id=16560 [Consulta: 20 de junio de 2020].

Segorbe, J.: Navegación para el cielo, En Valencia, por Felipe Mey, 1611.

Serlio, S.: Libro estraordinario di Sebastiano Serlio Bolognese nel quale si dimostrano trenta porte di opera rustica mista con diuersi ordini, In Venetia, Appresso Francesco Senese, \& Zuane Krugher Alemanno, compagni, 1566. Véase http://bdh-rd.bne.es/viewer.vm?i$\mathrm{d}=0000231696$ \&page $=5$ [Consulta: 20 de junio de 2020].

- Libro primo [-quinto] d'architettura di Sebastiano Serlio bolognese, nel quale con facile \& breue modo si tratta de primi principij della geometría. Con nuoua aggiunta delle misure che seruono a tutti gli ordini de componimenti, che ui si contengono, In Venetia, Appresso Francesco Senese, \& Zuane Krugher Alemanno, compagni, 1566.

Simon, G.: Archéologie de la vision. L'optique, le corps, la peinture, París, Seuil, 2003.

Simonetti, C.M.: La vita delle "Vite" vasariane: profilo storico di due edizioni, Florencia, Olschki, 2005.

Thébaud-Sorger, M.: "Spectacles de sciences", en Van Damme, S. (dir.), Histoire des sciences et des savoirs. De la Renaissance aux Lumières, Paris, Seuil, 2015, pp. 132-153.

Vasari, G.: Le vite de più eccellenti architetti, pittori et scultori italiani, Florencia, L. Torrentino, 1550, https://gallica.bnf.fr/ark:/12148/bpt6k123255q [Consulta: 20 de junio de 2020].

Vega Carpio, L.: Comedia de san Segundo compuesta por Lope de Vega, BNE, MSS/14767, fols. $123 \mathrm{r}-147 \mathrm{v}$, http://bdh-rd.bne.es/viewer.vm?id=0000186910\&page $=1$ [Consulta: 20 de junio de 2020].

- La dama boba: edición crítica y archivo digital, Presotto M. (dir.) con la colaboración de Boadas, S., Maggi, E. y Pessarrodona, A., Barcelona/Bologna; Prolope/Alma Mater Studiorum - Università di Bologna, 2015.

Vega, D.: Parayso de la gloria de los santos donde se trata de sus prerogatiuas y excelencias, tomo primero, Barcelona, en la Emprenta de Gabriel Graells y Giraldo Dotil, 1604. 